\title{
Social Class, Union Strategies, and Preference in Wage Outcomes in Norway'
}

\section{Ann Cecilie Bergene ${ }^{2}$}

Senior researcher, The Nordic Institute for Studies in Innovation, Research and Education (NIFU), Norway. ORC-ID: 0000-0001-5193-9956

\section{Ida Drange}

Research professor, the Work Research Institute, OsloMet - Oslo Metropolitan University, Norway. ORC-ID: 0000-0002-1762-4341

\begin{abstract}
This article explores a potential socialization effect of unions on member preferences in wage outcomes and bargaining structures. This challenges notions of union wage policies simply reflecting the material self-interest of their constituency. In their formative role, unions can either propagate more redistribution in society, that is, increasing equality, or increasing societal inequalities, arguing instead for equity. However, equity could be measured either individually or collectively, where the latter would mean increasing societal wage inequalities while favouring intra-union equality. By putting perspectives on worker preferences and political economic theories in dialogue with the literature on the role of unions in constructing notions of equality/equity, we discuss on union strategy as it relates to their socialization effects and members' attitudes towards income inequality and bargaining structures. Analysing survey data, we find that socioeconomic status has greater influence on preferred wage outcomes, while union membership has more influence over bargaining structure.
\end{abstract}

\section{KEYWORDS}

Union profile / wage inequality / equity / collective wage bargaining / union preferences

\section{Introduction}

espite income redistribution being a normative ideal in European welfare societies, preferences when it comes to wage outcomes and bargaining structures have been largely neglected in the research literature, being only to a limited extent explored as cross-national variations (Osberg \& Smeeding 2006; Checchi et al. 2010; Arndt 2018). Furthermore, research on attitudes towards wage setting and inequality has been overtly focused on structuralist explanations of social class position (Scheuer 1986; Ritzman \& Tomaskovic-Devey 1992; Barth et al. 2003; Checchi et al. 2010; Pernicka \& Lücking 2012). The role of unions in shaping the perception of interests and attitudes among members has thus been largely ignored, with Arndt (2018), Kim and Margalit (2017) and Mosimann and Pontusson (2017) being notable exceptions.

\footnotetext{
${ }^{1}$ You can find this text and its DOI at https://tidsskrift.dk/njwls/index.

${ }^{2}$ Corresponding author: ann.cecilie.bergene@nifu.no.
} 
Kim and Margalit (2017) argue that unions have a formative role on their membership in their role as information providers. In a similar vein, the contributions of Arndt (2018) and Mosimann and Pontusson (2017) point out that the preferences among union members of the same socioeconomic background varies with union profile.

According to Mosimann and Pontusson (2017), the preference for redistribution is stronger among members that belong to unions that display a combination of high density and organising in more or less equal measure low- and high-wage workers, and that this is particularly true among the high-wage earners. Arndt (2018), on the other hand, discloses that this only holds when the higher earners are members of blue-collar unions, as members of white-collar unions tend to be more oriented towards market allocation of income. Hence, this research indicate that union members are not homogeneous, not even within the same social class, and that union profile matters across the wage distribution, as well as within high- and low-wage strata.

Our analysis focuses on precisely such a formative effect of different union confederations when it comes to constructing solidarity across and within educational and income groups. The main contribution of this article is to demonstrate the likelihood of a socialization effect of unions on member preferences by exploring the explanatory power of union membership alongside that of social class by distinguishing the influence of social economic status from that of union membership when it comes to preferences in wage outcomes and bargaining structures. Our research question is: to what extent are preferences of wage outcomes and bargaining structure shaped by union membership? To answer this, we will investigate individual support for wage compression and for (de)centralised bargaining based on survey data consisting of a representative sample of Norwegian workers in the period 2015-2019.

In our view, Norway is a particularly interesting case for such a venture. The union movement in Norway is, along with the other Nordic countries, among the most classsegmented in the world (Kjellberg 2000; Arndt 2018). Occupational class interests and union strategy may thus be more strongly associated here. Furthermore, highly educated workers in Norway would be free to choose between affiliation to four different union confederations, which differ quite substantially on the question of income inequalities and bargaining structures. Recent union growth has largely occurred in professional associations seeking to achieve and maintain privilege and traditional closure strategies in collective bargaining (Wallerstein \& Golden 1997; Campbell \& Haiven 2011; Arndt 2018). This might lead to diverging interests in the union movement (Scheuer 1993; Barth et al. 2003; Arndt 2018). Lately, Norwegian professional associations have started to question the fairness of compressed wage structures, drawing on discourses of equity and 'fair share (Fennefoss et al. 2000: Fennefoss \& Høgsnes 2002, 2004, 2006, 2008). As such, the Norwegian context will, to a larger extent than its Nordic neighbours, provide fertile grounds to observe whether the political stance of unions is reflected in members' attitudes.

The article builds on the emerging research on different union interests (Arndt 2018; Kim \& Margalit 2017). Our data are of excellent quality. It contains information about which federation to which union members belong, education level and wage income. With our data, we can observe differences between individuals within the same socioeconomic strata according to membership of union confederations. Moreover, the data contain information about gender and age, sector, industrial sector, part-time employment, management position and political voting behaviour. The latter allows us 
to exhaust most of the competing explanations of attitude formation, for example 'rightwing' alliances. With these data, we can do robust analyses of variation in attitudes and preferences among employees according to union confederation. We cannot disentangle the endogeneity present in union membership and the influence of unions on peoples' political opinions with cross-sectional data, but this is a minor concern given our aim first and foremost being to demonstrate the plausibility of a union socialization mechanism.

\section{Social class as a predictor of attitudes towards redistribution}

Most of the literature on preferences for redistribution has, according to Pontusson (2013), a distinctly individualist orientation, meaning that it largely analyses individual preferences as these derive from material self-interest, for example will the individual worker gain or lose from redistribution? In this view, individual preferences for redistribution will solely depend on their social class position and exposure to risk, which is determined by their income level, skill composition, occupation and employment relations (Iversen \& Soskice 2001; Alt \& Iversen 2017). Hence, the preference and support for redistribution policies, including the wage policies of unions, will be inversely related to income and employment security. This is because strictly self-interested individuals would not rationally be willing to shoulder the costs of contributing to any 'public good' derived from unionization (Pernicka \& Glassner 2014). Workers finding themselves at the upper end of the labour market, with job security deriving from skills and with high wages would presumably be least willing to do so. Moreover, these workers would not view collective organization as optimal in wage negotiations, standing to gain more from making individual wage claims (Mosimann \& Pontusson 2017; Arndt 2018).

Presuppositions about the primacy of economic returns have given rise to theoretical contributions seeking to understand unions as the aggregate of each individual member's perceived material self-interest, or alternatively, that unions portray themselves as catering for these perceived self-interests to attract members. Analyses of this kind often seek to identify separate 'union profiles' based on the socioeconomic background of their (potential) members. In this strand of thought it is regarded as one of the main tasks of unions to preserve and improve the current wage level of their members, even to the disadvantage of other unionized workers (Elster 1989: 121). In Scheuer's (1986) framework this means that highly educated workers would form professionaloriented unions seeking to increase the status for their constituency to the detriment of strategies aimed at equalisation. It follows that unions representing low-skilled workers will be more solidaristic and bent on equalisation of wages, compared to white-collar unions representing high-skilled workers (Arndt 2018). Studies based on European data to some extent corroborate this. According to Becher and Pontusson (2011), employment conditions and skills give rise to divergent preferences, and relative income is a significant predictor of attitudes towards redistribution polities. Professionals and associate professionals hold negative attitudes towards governmental income redistribution, while skilled and unskilled workers are in favour of such policies (Svallfors 1993, 1997; Kitschelt \& Rehm 2014; Arndt 2018). Interestingly, such class differences are most prominent in Scandinavia (Svallfors 1993, 1997). 
However, the notion that union policy solely emerge from members' interest has several caveats. First of all, it presupposes that workers organise either because they (a) hold egalitarian opinions and select a union representing their opinions, and/or (b) they are not overtly concerned by the effects of egalitarian policies on their own material interests, and that this situation is static and not subject to change. As recognized by Alesina and Giuliano (2009), economic theories tend to presume that individuals have preferences defined over their lifetime. This leads them to emphasise the role of historical experiences, cultural factors and personal history when studying individual preferences for equality. Secondly, there is the issue of interest aggregation and homogeneity among union members. According to Pontusson (2013), much of the literature on preferences regarding redistribution does not deal properly with unions at all, and even less with how individual members' preferences are aggregated. Although leaving a thorough examination of the mechanisms of preference aggregation for future research, Becher and Pontusson (2011) are critical of the assumption that the union constituency is by and large homogeneous, sharing a common perception of material and political interests.

If we were to assume that unions simply aggregate the policy preferences of a homogeneous constituency, for instance through majority rule, Becher and Pontusson (2011) find it reasonable to presume that the location of union members along the income distribution would affect the extent to which their policies endorse redistribution. This would also mean that different unions within the same country would organise workers with more or less the same attitudes towards income redistribution, and thus that the unions would devise more or less redistributive policies depending on what segments of the income distribution they organise.

However, Becher and Pontusson (2011) do not find evidence to support this when comparing craft/occupational and industrial unions across national contexts, including when considering the Nordic countries in which there are separate white-collar and blue-collar unions, and, as in Norway, even competition between them for the same (potential) members. Based on their findings, Becher and Pontusson (2011) propose that one interpretation of this is that unions promote solidarity among their members, even though their immediate material interests would not necessarily lead them to support such notions. This leads us to studies of the formative role of unions, and the effects of union membership on members' preferences in wage outcomes and bargaining structures.

\section{The union factor: How unions' influence preferences for redistribution and collective action}

The objective in this article is to investigate whether unions have an independent effect on attitudes above and beyond socioeconomic status (SES). Recent research substantiates that union strategy influence members' preferences. As pointed out by Pontusson (2013:798), even though all union members are more supportive of egalitarianism and redistribution than non-union workers, this is even more so among members with high (household) incomes.

In Kim and Margalit's (2017) study of the influence unions exert on the attitudes of their members, they make a compelling case for a socialization effect since self-selection 
into union membership only accounts for at most a quarter of the observed union effect. This leads Kim and Margalit (2017) to conclude that unions are not merely the aggregate voice of workers' individual self-interest, but rather that unions do influence the views of their membership in a meaningful way. Similarly, Pontusson (2013) draw on the so-called 'power resources theory' (PRT), assigning as it does a key explanatory role to unions. With this as a point of departure, Pontusson (2013) argues that his own compelling evidence against basing any explanations of an association between union membership and support for redistribution solely on self-selection, suggests that self-selection and union effects should not be regarded as mutually exclusive.

One way of assigning explanatory power to unions, is to, by means of organisational-political analyses, turn our attention to the larger project of building union identities (Fennefoss 1996). Such analyses are built upon the presupposition that the notion that classes exist objectively in themselves underestimates, or even neglects, the profound influence unions have in forming and shaping social classes and attitudes. Focusing instead on the subjective dimension of classes for themselves means that the very activities of groups, such as unions, serve to change them substantively and substantially (Castree et al. 2004). Discourses of fairness are both constructed and drawn upon by unions, shaping the frame of reference and the experiences of workers (Jones 1983). The distinction between class in itself and for itself furthermore reminds us that the consciousness of classes is not a constant but a variable. Any antagonisms between social classes on the question of wage distribution result from the construction of solidarity and the constitution of the class for itself. Attitudes of union members are conditioned by ongoing struggles over classifications and negotiations over identities in the union movement.

As argued by Alesina and Giuliano (2009), individuals' attitudes regarding redistribution and acceptable levels of social inequality are intertwined with political ideology and notions of what is (un)fair. Checchi et al. (2010) thus argue that union membership cannot be regarded as solely the result of a rational choice based on instrumental considerations related to relative earnings. In their view, union membership is also the result of unions expounding a philosophy of egalitarianism and basing their actions on claims toward contributing to more fairness in the labour market.

There are, however, two competing norms fairness in the union movement; equalisation and equity, both of which are legitimate claims in wage negotiations with quite different impacts on wage distribution. Equalisation entails reduction of inequality, prioritising low-wage earners in negotiations. Equity, on the other hand, entails remuneration bend on endowment or effort, potentially resulting in increased wage inequality based, for instance, on different levels of productivity (Høgsnes 1989: 345). To the extent that unions' profiles affect members' preferences, we expect to find a stronger support for redistribution and collective wage bargaining among union members in unions with a clear equalisation profile in contrast to members of white-collar unions (Mosimann \& Pontusson 2017; Arndt 2018).

Because we use survey data in our inquiries, we cannot rule out reversed causality, that is that workers choose unions that mirror their political views and preferences for redistribution. The theoretical arguments, and previous research findings, however, provide sufficient support to suggest the plausibility of a union effect. Our analytical strategy, described in the method section, exhausts alternative explanations to the association between attitudes and confederations with a wide control of confounding variables. 


\section{The Norwegian context}

The Norwegian union movement is a good example of how the triple tension pointed out by Hyman (2001) between market, society and class has given rise to a variety of ideological orientations and union identities. Particularly the last 40 years, there has been an emergence of new, occupation-specific union confederations.

There is at present four union confederations in Norway, organising both along the blue-/white-collar divide and within the group of white-collar workers. The four confederations differ in terms of their historical legacy and their orientation to the Labour Party. They are also different when it comes to level of centralization, union strategies and their size, as well as the industries their affiliates organise and the occupational character of their individual members (Bergene \& Mamelund 2015). The organisations are LO (Landsorganisasjonen i Norge, The Norwegian Confederation of Trade Unions), YS (Yrkesorganisasjonenes Sentralforbund, The Confederation of Vocational Unions), Unio (Confederation of Unions for Professionals) and Akademikerne (The Federation of Norwegian Professional Associations). While LO and YS mainly organise blue-collar workers and vocational occupations, Unio and Akademikerne organise only professional occupations. Table 1 summarises information about the scope and membership of the confederations.

Table I Union confederation profile

\begin{tabular}{llcc}
\hline & Members & Founded & Membership \\
\hline LO & Primarily vocational occupations & 1899 & 800,000 \\
\hline YS & Primarily vocational occupations & 1977 & 220,000 \\
\hline Akademikerne (former AF) & Professional occupations & 1997 & 170,000 \\
\hline Unio & Professional occupations & 2001 & 320,000 \\
\hline
\end{tabular}

Table 2 shows the distribution of each educational group across the confederations. As we can see, only LO feature an even distribution of members across all education levels, while the majority of YS members have basic, vocational or lower tertiary education. Unio primarily represent members with tertiary education and Akademikerne represent members with higher tertiary education. The elite professions, for example medical doctors, lawyers and economist, are organised in Akademikerne, while the welfare-state professionals are organised in Unio.

Table 2 Education level across confederations (waves: 20|4-2019). Numbers in percent, $\mathrm{N}=11,696$

\begin{tabular}{lccccccc}
\hline & LO & YS & Unio & $\begin{array}{c}\text { Akade- } \\
\text { mikerne }\end{array}$ & $\begin{array}{c}\text { Indep- } \\
\text { endent }\end{array}$ & $\begin{array}{c}\text { Do not } \\
\text { know }\end{array}$ & $\begin{array}{c}\text { Not a } \\
\text { member }\end{array}$ \\
\hline Basic education & 29 & 28 & 1 & 0 & 9 & 9 & 31 \\
Vocational education & 37 & 31 & 2 & 1 & 19 & 14 & 25 \\
Bachelor & 24 & 30 & 48 & 16 & 52 & 47 & 31 \\
Master & 10 & 11 & 49 & 82 & 19 & 301 & 13 \\
\hline Total & 100 & 100 & 100 & 100 & 100 & 100 & 100 \\
\hline
\end{tabular}


Survey data from 1989 and 1993 show members of LO being more in favour of equalization compared to YS and the former Akademikernes Fellesorganisasjon (AF) (Academic and Professional Unions), while members of AF displayed preferences for more inequality and equity in wage determination (Høgsnes 1999: 63). AF was disbanded in 1997 and is the predecessor of both Akademikerne and Unio as its affiliates went separate ways out of disagreements regarding bargaining structures. This meant that some of the former affiliates of Akademikernes Fellesorganisasjon ( $A F$ ), among them the unions for teachers, nurses and police officers, and at a later stage the scientists and researchers, were not willing to join Akademikerne out of opposition to their strategy of local negotiations. For the former AF unions, joining LO was not an option due to its narrow blue-collar definition of worker and their affiliation to the Labour Party (Messel 2010), and instead they formed Unio in 2001. Today Unio and Akademikerne still fundamentally disagree on the question of central local versus local bargaining respectively. This became apparent in the 2014 and 2016 negotiations, when Akademikerne stated explicitly that they were in favour of decentralizing wage bargaining to the local or even individual level (Fennefoss and Høgsnes 2008), and signed their own collective agreement. They did so drawing on discourses of equity, arguing in favour of differentiating 'on the basis of education, qualifications/skills, knowledge, effort and responsibility'. Akademikerne also take a normative stance in the direction of greater acceptance of societal differentiation.

To a greater extent than Akademikerne, Unio try to balance market and social interests, and thus draw both on discourses of equity and a broader notion of societal solidarity and equality. As stated on their website, Unio 'actively participates in labour policy, with a broad societal engagement', prioritising 'an incomes policy where both blue- and white-collar workers are included' and 'collective, central agreements acting as a necessary framework for local adjustments' (our translation). At the same time, as we can see, they do acknowledge the need for local adjustments, and it seems fairness is defined as '[w]ork of equal value should be paid equally', meaning 'better wages based on education and skill'. We can thus discern references to both discourses of equity and of societal solidarity and equality.

LO has been a central player in the development of the Norwegian welfare society and the tripartite model of industrial relations, being signatory to the first Basic Agreement in 1935. As such, it has a strong commitment to 'societal solidarity' as opposed to 'class solidarity', entailing an active involvement in wage moderation through coordinated collective bargaining, the so-called frontfagsmodellen [the leading sector model] (Hernes 2006). Frontfagsmodellen ensures that the collective bargaining results in industrial sectors exposed to international competition set the standards for other to follow, thus compressing the wage structure in Norway. LO explicitly draw on a discourse of equalisation, also stating explicitly that collective agreements should be centralised and nation-wide.

YS was established in 1977, and was meant as a politically independent alternative to LO. Furthermore, compared to LO, YS has historically had a larger proportion of clerical workers, including workers with higher education, though not many professionals (cf. Tables 2 and 4 that show more YS members with lower tertiary education).

Despite our results (Table 4) show rather small differences in composition between LO and YS, YS is more sectorally organised, with YS Public sector and YS Private sector as strong internal sections. Referring to this, a YS union official claimed in personal communication that, as a result, YS has a more heterogeneous constituency than the 
other union confederations. Regardless of the truth-content of this statement, such selfperception may partly explain why YS has the least clear policy of the four. When asked about their wage policy, the informant replied that 'YS has probably not composed a short and unambiguous policy'. Our informant expressed that YS is 'not happy about' the observed increasing wage inequalities in Norway, while at the same time stressing that 'this does not mean that [YS] is against there being wage differentials, only that they are becoming too great' (personal communication). When trying to reflect on what 'too great' means, the informant drew neither on the principle of equity nor equality, only the sheer quantitative gap, meaning that the question could not be answered: 'I think it is next to impossible to say precisely how great the wage differences in society should be'. There are no clear formulations in their official wage policy as to why there should be wage differentials, the closest being the argument that all workers should be ensured a good wage development and their fair share of wealth creation.

\section{Research topic}

We analyse two variables relating to attitudes on wage inequality and bargaining preference to investigate whether unions have an independent effect on these beyond that of SES. These questions are central to union strategies, as the confederations have stakes in (re)establishing bargaining structures and in compressing or increasing the wage differentials which have dominated the negotiations since year 2000. The influence of unions on the attitudes and preferences of their members will probably apply to the greatest extent in questions where unions take a clear stance and engage in public discourse. Moreover, wage negotiations are of direct interest to workers, and are likely to inform their choice of union membership. We may therefore assume that members are, in general terms, familiar with the policies of the confederation to which they belong, and especially so during a period in which the confederations explicitly differ in their strategies with material outcomes.

The first variable is based on a question pertaining to whether wage inequalities in Norway ought to be smaller, stay the same or increase. Considering the dominant position of LO in the Norwegian politico-economic context, and the general support of equalisation and wage moderation, we would expect members of Akademikerne and Unio to show a stronger preference for increased wage differentials, also after adjusting for SES (H1). This because Akademikerne and Unio have advocated the allocation of a higher share of generated surplus to higher educated workers on the basis of notions of equity (Fennefoss \& Høgsnes 2008).

The second variable measures workers' bargaining preferences. Centralised wage agreements (CWA) are vital for restraining increasing wage inequalities. Considering that the low-skilled and skilled workers so far have benefited more from CWAs compared to the high-skilled, we posit that the low-skilled and skilled workers are more likely to display a preference for centrally negotiated agreements. Due to a stronger bargaining position vis-à-vis employers from which to make wage claims, (Silver 2003) we would expect highly skilled workers to prefer local wage setting, negotiated either individually or by union representatives As we have seen, the union confederations have diverging policies on bargaining structure. If we observe diverging preferences within similar SES-groups, we consider this a union effect (H2).

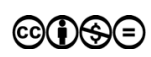




\section{Data}

The survey data consist of seven waves of the YS Employee Working Conditions Surveys, covering the years 2014-2019. The YS EWCS is an annual cross-sectional survey of a nationally representative sample of the working population aged 18-68 years. The inclusion criterion is that respondents work a minimum of two days a week (i.e., a $40 \%$ position).

TNS Gallup gathers the data according to a stratified sampling procedure. There is an underrepresentation of young men with low education in the sample, due both to recruitment and non-response biases (see Bergene \& Mamelund (2015) for more information on data gathering and sampling procedures). Union members are overrepresented in the net sample, and the share of union members varies between $64 \%$ and $68 \%$ in the seven waves of this study. This is approximately ten percentage points higher than the corresponding figure for the population. Moreover, members of LO and YS are overrepresented, while Unio and Akademikerne are underrepresented. The sampling weight adjust for sampling bias according to age, education and gender. We analysed the data with and without sampling weights. Weighting the sample did not change the direction or significance of our main results. Sampling weights are superfluous once the multivariate analyses include gender, age and education. Furthermore, the purpose of the descriptive statistics is to describe sample characteristics - and not population characteristics. For this reason, sample weights were not employed in the descriptive tables nor in the regression analyses.

\section{Dependent variables}

The dependent variables cover aspects of wage formation and attitudes towards equalization and collectivism. We analyse responses to two statements.

The first statement was 'In your opinion, should the wage differences in society become greater, smaller or stay at the current level?' The response alternatives were 'smaller', 'as is', 'greater' and 'do not know'.

The second statement included a preamble explaining the motivation for wage bargaining at central, local and individual level, respectively. The statement read: 'Wage negotiations take place at different levels. National (central) negotiations between the social partners take the state of the country's economy into account and/or seek to avoid creation of large wage differences; negotiations at the company level will, for example, consider the business finances, whereas individual negotiations will consider each employee's qualifications and performance. In your view, should wage bargaining take place between': 1) Unions and employer associations at a national level (centralised), 2) Union representatives and employers at company level (local), 3) the employee and the employer (individualised) and 4) Do not know. See Table 3 for descriptive statistics on the dependent variables.

\section{Independent variables}

The main independent variables are union confederation membership, education level and wage incomes. The variable union confederation membership is a nominal category 
variable identifying members of affiliates of LO, YS, Unio and Akademikerne, members of independent unions, unorganised workers and a remainder category consisting of people who do not know which confederation they belong to. ${ }^{1}$ The education level and wage income variables are combined into a SES index that measure workers' socioeconomic position. The rationale is that education and income combined better capture the different dispositions of workers in similar occupational positions, than education and income averaged over the sample. Table 3 displays the categorization of the SES measure and Table 4 displays the confederations' profile across SES-groups.

Table 3 The classification and distribution of SES (2014-2019). N = I I,696

\begin{tabular}{llcc}
\hline Socio-economic status & Education level & Wage position & Percent \\
\hline ( I) Unskilled workers, low wage & Elementary and High school & I.-7. decile & 17\% \\
\hline (2) Skilled workers, low wage & Vocational education & I.-6. decile & 15\% \\
\hline (3) Unskilled and skilled workers, high wage & Elementary and High school & 8.-10. decile & I3\% \\
& Vocational education & 7.-10. decile & \\
\hline (4) Highly skilled workers, low wage & Bachelor degree & I.-5. decile & 21\% \\
& Master's degree & I.-4. decile & \\
\hline (5) Highly skilled workers, medium wage & Bachelor's degree & 6.-9. decile & $25 \%$ \\
& Master's degree & 5.-8. decile & \\
\hline (6) Highly skilled workers, high wage & Bachelor's degree & 10. decile & 9\% \\
& Master's degree & 9.-10. decile & \\
\hline
\end{tabular}

Table 4 The distribution of Union Confederation per SES (20 |4-2019). N = | I,696

\begin{tabular}{|c|c|c|c|c|c|c|c|}
\hline & LO & YS & Unio & Akademikerne & Independent & $\begin{array}{l}\text { Do not } \\
\text { know }\end{array}$ & $\begin{array}{c}\text { Not a } \\
\text { member }\end{array}$ \\
\hline $\begin{array}{l}\text { (I) Unskilled work- } \\
\text { ers, low wage }\end{array}$ & $25 \%$ & $24 \%$ & - & - & $4 \%$ & $7 \%$ & $23 \%$ \\
\hline $\begin{array}{l}\text { (2) Skilled workers, } \\
\text { low wage }\end{array}$ & $25 \%$ & $21 \%$ & - & - & $6 \%$ & $8 \%$ & $16 \%$ \\
\hline $\begin{array}{l}\text { (3) Unskilled and } \\
\text { skilled workers, } \\
\text { high wage }\end{array}$ & $17 \%$ & $14 \%$ & - & - & $18 \%$ & $8 \%$ & $17 \%$ \\
\hline $\begin{array}{l}\text { (4) Highly skilled } \\
\text { workers, low } \\
\text { wage }\end{array}$ & $18 \%$ & $20 \%$ & $40 \%$ & $15 \%$ & $18 \%$ & $40 \%$ & $16 \%$ \\
\hline $\begin{array}{l}\text { (5) Highly skilled } \\
\text { workers, } \\
\text { medium wage }\end{array}$ & $13 \%$ & $17 \%$ & $52 \%$ & $48 \%$ & $40 \%$ & $29 \%$ & $18 \%$ \\
\hline $\begin{array}{l}\text { (6) Highly skilled } \\
\text { workers, high } \\
\text { wage }\end{array}$ & $2 \%$ & $4 \%$ & $5 \%$ & $35 \%$ & $14 \%$ & $8 \%$ & $10 \%$ \\
\hline $\begin{array}{l}\text { Total number of } \\
\text { observations }\end{array}$ & 3444 & 1179 & 1404 & 1030 & 516 & 492 & 3631 \\
\hline
\end{tabular}


We have experimented with different cut-offs for wage, and the results are highly robust to specification. In appendix $\mathrm{A}$, an analysis displays the results for a regression with separate measures of wage income and education level.

\section{Control variables}

The control variables are age and age squared, gender, industrial sector, public/private sector, part-time employment, supervisory/management position, current wagesetting arrangement and party-political preference. These variables are likely to confound the relationship between SES, union confederation membership and preferences with regard to wage inequalities and wage setting. Table 5 displays the descriptive statistics.

Table 5 Descriptive statistics (waves: 2014-2019). N = | 1,696

\begin{tabular}{lccc}
\hline Women & $52 \%$ & Political party affiliation & \\
Public sector & $47 \%$ & Labour party (AP) & $27 \%$ \\
Business/industry & & Progress party (FrP) & $10 \%$ \\
Public admin., incl. services & $14 \%$ & Conservative party (H) & $23 \%$ \\
Education & $14 \%$ & Pol. centre parties (V, SP, KrF) & $13 \%$ \\
Health and social service & $15 \%$ & Socialist left party (SV) & $6 \%$ \\
Industry & $25 \%$ & Other & $4 \%$ \\
Trade and services & $21 \%$ & No answer & $17 \%$ \\
Creative and academic occ. & $6 \%$ & Wage agreement & \\
Other & $4 \%$ & Collective wage agreement & $70 \%$ \\
Part-time & $12 \%$ & Individual wage settlement & $30 \%$ \\
Manager & $27 \%$ & Mean age: 46.7 years & \\
\hline
\end{tabular}

\section{Regression methods and analytical strategy}

Both of the dependent variables in our analyses are nominal-level variables with two or more categories. We therefore apply multinomial logistic regression. All models have been tested for violations of the regression assumptions.

Logistic regressions investigate how the likelihood of one outcome, on a dichotomous variable, increases or decreases with group-level characteristics. The multinomial logistic analyses extend the logistic model to several outcomes. The model compares the effects of the independent variables on the likelihood for any given outcome with a base category, which gives the coefficients a relative interpretation. Because many people do not have a strong opinion on wage distribution and wage setting, we include those who answer, 'I do not know' in the analyses, but not in the presentation of results. Hence, presented likelihoods do not cumulate to one. We calculate predicted probability and marginal effects of union membership averaged over the other variables in the models. 
Our analytical strategy is to first show differences according to union confederation membership, we then add SES and the different control variables. This will illustrate how much SES and other controls explain the observed, bivariate effect of union confederation in model 1 . If any differences remain between the confederations after adjusting for SES, individual characteristics, political affiliation and occupational characteristics, we attribute this independent effect of confederations to union identity and a socialisation effect. More precisely, we consider our hypothesis of the formative role of union policy strengthened if we are unable to explain the association between attitudes and confederations with plausible confounding variables. $^{2}$

\section{Results}

\section{Attitudes towards wage dispersion}

The results from the first analysis appear in the first column of Table 6a. It shows that a majority of workers, independent of confederation membership, actually prefers a reduction in wage inequalities. A graphic display of these numbers is presented in Figure 1a.

Figure Ia Preference for wage differences according to Union Confederation membership.

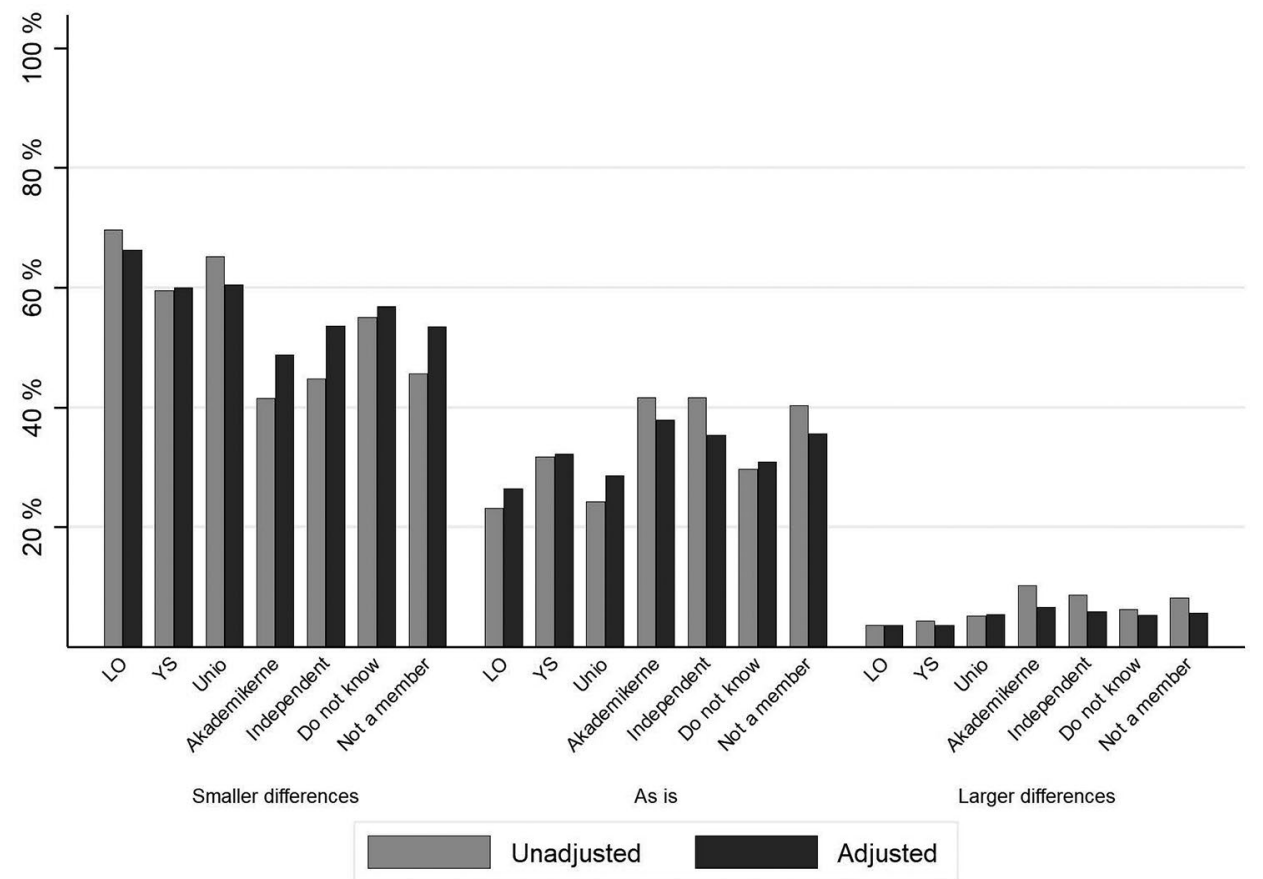


The share is highest among LO members (70\%), followed by Unio members $(65 \%)$, YS $(60 \%)$ and Akademikerne $(41 \%)$. The second most frequent preference is for maintaining current levels of wage inequality. Here, the rank is reversed, with most support among members of Akademikerne (42\%), followed by YS (32\%), Unio $(24 \%)$ and LO $(23 \%)$. Lastly, those most in favour of increased wage differences are found among members of Akademikerne (10\%), followed by Unio (5\%). The members of YS and LO members to a lesser extent express this opinion, with only $4 \%$ in both confederations. However, given the different composition of the memberships, we need to adjust for socio-economic position and other relevant background characteristics.

Table 6a Multinomial logistic regression. Preference for smaller and larger societal wage differences. 'As is' is the reference category

\begin{tabular}{|c|c|c|c|c|c|c|c|c|}
\hline \multirow[b]{3}{*}{ Independent variables } & \multicolumn{4}{|c|}{ Unadjusted } & \multicolumn{4}{|c|}{ Adjusted } \\
\hline & \multicolumn{2}{|c|}{$\begin{array}{c}\text { Smaller } \\
\text { differences }\end{array}$} & \multicolumn{2}{|c|}{$\begin{array}{c}\text { Larger } \\
\text { differences }\end{array}$} & \multicolumn{2}{|c|}{$\begin{array}{c}\text { Smaller } \\
\text { differences }\end{array}$} & \multicolumn{2}{|c|}{$\begin{array}{c}\text { Larger } \\
\text { differences }\end{array}$} \\
\hline & logit & Se & logit & se & logit & se & logit & se \\
\hline \multicolumn{9}{|c|}{ Union Confederation (ref: LO) } \\
\hline YS & $-0.47 \mid$ ****** & 0.076 & -0.139 & 0.178 & $-0.296 * * * *$ & 0.083 & -0.193 & 0.182 \\
\hline Unio & -0.114 & 0.075 & 0.299 & 0.161 & -0.172 & 0.093 & 0.318 & 0.186 \\
\hline Akademikerne & $-1.105^{* * * *}$ & 0.080 & $0.456 * *$ & 0.145 & $-0.668 * * *$ & 0.096 & 0.225 & 0.167 \\
\hline Independent & $-1.029 * * * *$ & 0.103 & 0.290 & 0.190 & $-0.505 * * * *$ & 0.115 & 0.195 & 0.201 \\
\hline Do not know & $-0.482 * * * *$ & 0.110 & 0.304 & 0.220 & $-0.310 *$ & 0.121 & 0.215 & 0.228 \\
\hline Not a member & -0.977 ****** & 0.054 & $0.257 *$ & 0.115 & $-0.5 \mid 3^{*} * * *$ & 0.067 & 0.143 & 0.133 \\
\hline \multicolumn{9}{|c|}{ Socio-economic status group (ref unskilled, low wage) } \\
\hline Skilled, low wage & & & & & 0.034 & 0.082 & 0.185 & 0.172 \\
\hline $\begin{array}{l}\text { Skilled and unskilled, high } \\
\text { wage }\end{array}$ & & & & & -0.795 ***** & 0.085 & -0.043 & 0.163 \\
\hline Higher education, low wage & & & & & -0.038 & 0.083 & 0.156 & 0.175 \\
\hline $\begin{array}{l}\text { Higher education, medium } \\
\text { wage }\end{array}$ & & & & & $-0.568 * * * *$ & 0.079 & 0.199 & 0.157 \\
\hline Higher education, high wage & & & & & $-1.183^{* * * * *}$ & 0.104 & $0.598 * * * *$ & 0.169 \\
\hline Control variables & & & & & & Inclu & ded & \\
\hline Constant & I. $10 \mid$ ***** & 0.041 & $-1.854 * * * *$ & 0.096 & 1.921 **** & 0.395 & $-2.204 * *$ & 0.748 \\
\hline$-2 \mathrm{LL}$ & $-\mid 1535.5$ & & & & -10485.2 & & & \\
\hline Df & 18 & & & & 102 & & & \\
\hline $\mathrm{N}$ & 11696 & & & & 11696 & & & \\
\hline
\end{tabular}

p-levels (* $0.05 * * 0.01 * * * 0.001$ ). Control variables in the adjusted model: gender, age, age squared, industrial sector, sector, part-time employment, management position, year and party political preference. 
The second column of Table 6 a presents the analyses with controls. This analysis shows a strong reduction of the differences between the confederations, although the general pattern remains. In line with our expectations, we find that confederations have an effect on the preferences for societal wage dispersion, after adjusting for SES and controls. The marginal effect, that is the change of likelihood associated with membership in YS, Unio, Akademikerne, independent confederations or for non-members relative to LO members, are substantial in magnitude (meaning that the marginal effect is equivalent to the gap between bar-height in Figure 1, adjusted values). The likelihood that YS members and Unio members prefer a lower level of wage dispersion in society, adjusted for controls, is 6 percentage points lower relative to LO members. For members of Akademikerne, the associated marginal effect is 17 percentage points.

The results show that the majority of workers in general prefer smaller wage inequalities, but this attitude is most widespread among members of LO, regardless of their position in the class schema. We list the percentage of workers who prefer a reduction in wage inequalities represented by confederation membership in descending order: LO $(68 \%)$, YS (60\%), Unio (60\%) and Akademikerne (50\%). Adjusting for socio-economic status does not alter the distribution with regard to preferring increased inequalities, except among members of Akademikerne. Adjusting for socio-economic status and controls reduce the share in favour of increasing wage inequality among the latter, and thus bring members of Akademikerne more in line with the preferences of members of the other confederations. Hence, part of the difference observed in the first column of Figure 1 is due to SES. People of high SES tend to be more in favour of a larger wage dispersion, and this bias the results towards preferring larger differences between members of confederations who organise lower SES and higher SES workers, respectively. Once we account for this difference, adjusting the analyses for SES and other confounding variables, the results display a convergence in preferences across membership status, but still we observe a substantial difference according to membership status that is not accounted for by SES or political preferences, as well as the other control variables.

The results in column 2 (Table 6a) and the predicted results in Figure 1a are averages across socio-economic status. Because the lower SES groups dominate the membership constituency of LO, and the higher SES groups dominate the constituency of Akademikerne, adjusted average effects can conceal differences in preferences among LO members according to SES. We have performed analyses of the membership in the four union confederations within SES groups, and the results are displayed in figure $1 \mathrm{~b}$ (see Table $6 \mathrm{~b}$ ). Because Unio and Akademikerne primarily organise members with higher education (cf. Tables 1 and 2), we include these confederations only in the SES-groups with higher education. We concentrate our discussion of preferences around 'smaller differences', because the significant differences between confederations are primarily found between those who answer 'smaller differences' and 'as is', and hence the results are inverse.

First, LO members in the unskilled and skilled low-wage groups are most in favour of smaller differences, whereas YS members in the skilled and unskilled high wage-group are most in favour of smaller differences. Non-members show the lowest preference for reduced differences.

In the higher education groups, LO members are most in favour of smaller differences, whereas members of Akademikerne show least preference for 'smaller differences' in the low- and medium-wage groups. However, in the high-wage group, members of LO display the highest preference for wage compression, whereas Akademikerne, Unio

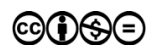


Figure I b Preference for wage differences within SES-categories according to Union Confederation membership.

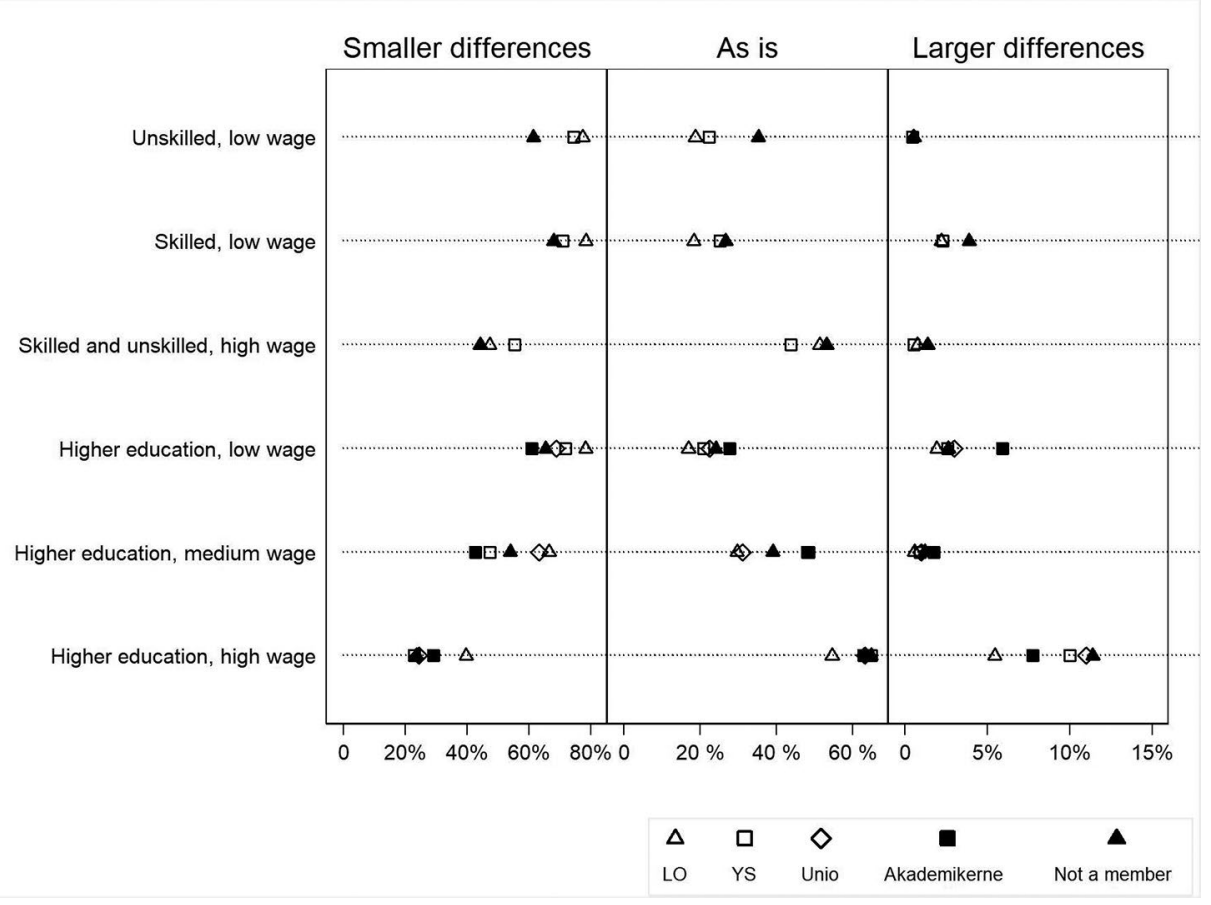

members, YS members and non-members show least preference for smaller differences. One possible explanation for this finding is that managers are overrepresented in the highest earner group among Unio members.

Figure $1 \mathrm{~b}$ also displays a clear wage and education gradient in preferences for societal wage inequalities. First, the lower the wage, the stronger the preference for redistribution, regardless of education level. Second, those with higher education display weaker preferences for smaller wage differences and a stronger preference for larger wage differences compared with unskilled and skilled workers in the high wage group.

The differences between members of the four confederations are significant with regard to the preference for decreasing wage dispersal relative to maintaining the current level of wage dispersal in society. However, there are no significant differences between confederation memberships with regard to the preference for larger wage dispersal, relative to maintaining the current level (see Table 6a).

\section{Preferred bargaining structures}

The final investigation is bargaining preferences, and it directly addresses the core conflict between the different confederations in the 2014 and 2016 negotiations. The results appear in Table $7 \mathrm{a}$ and in Figure 2. 

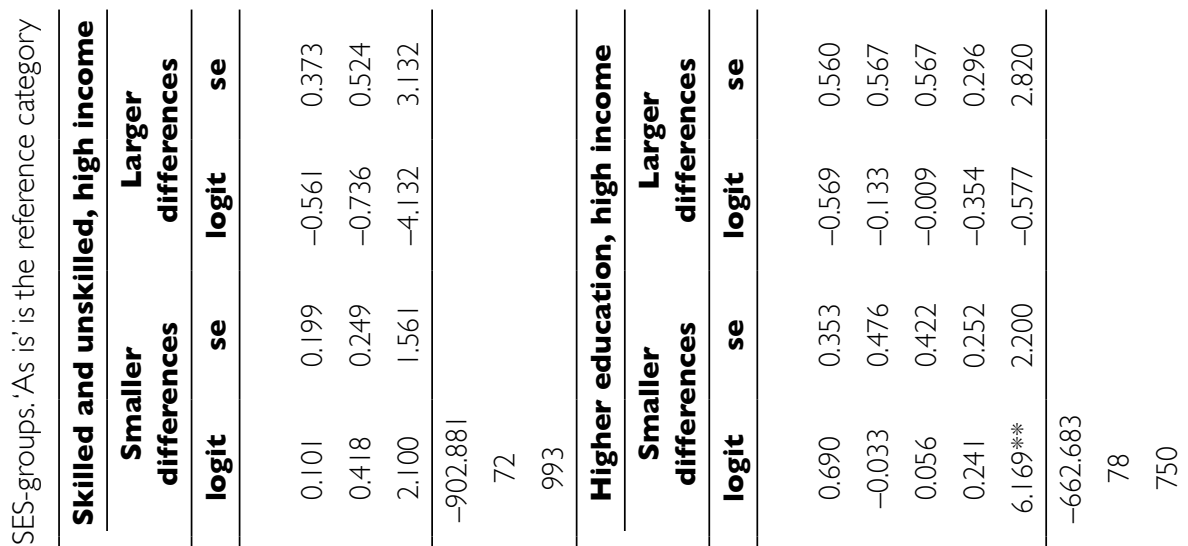

$\frac{. \subsetneq}{\frac{1}{3}}$
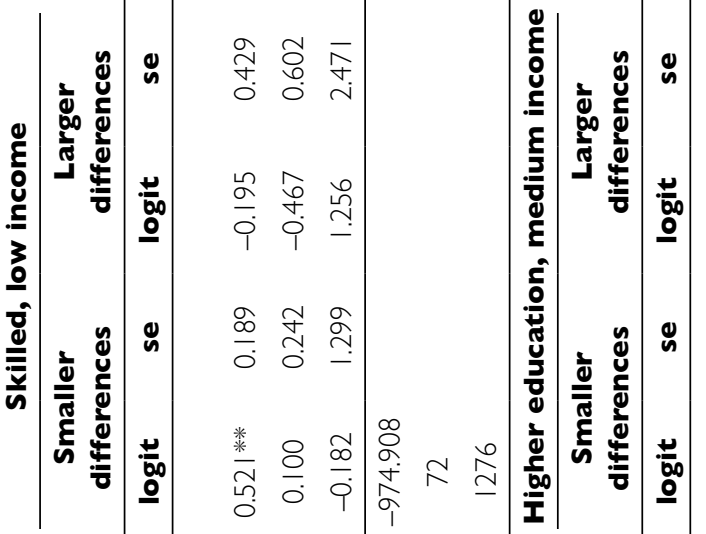

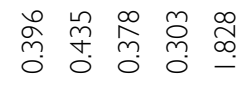

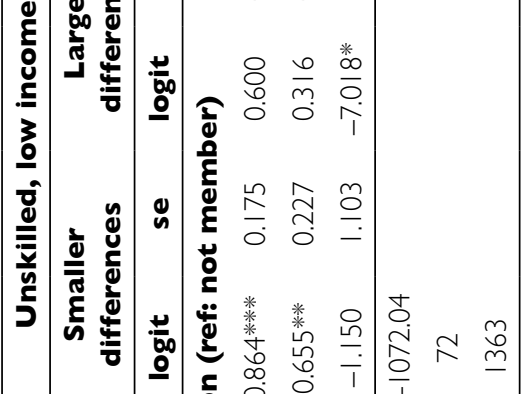

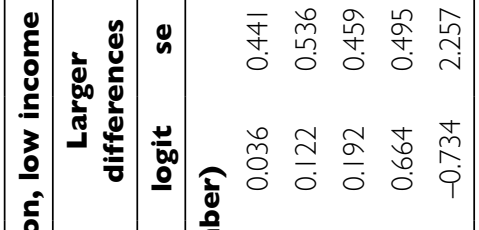

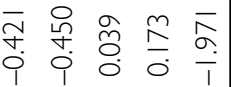

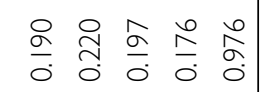

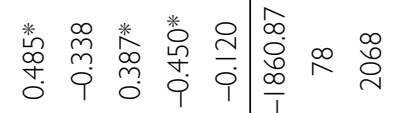

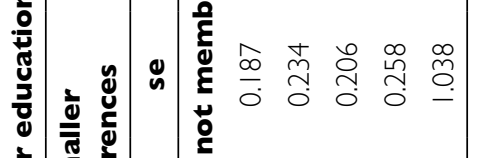

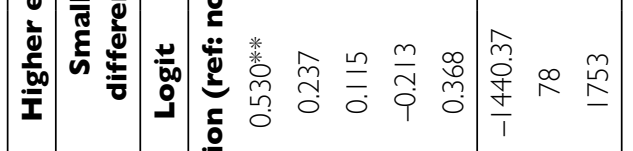

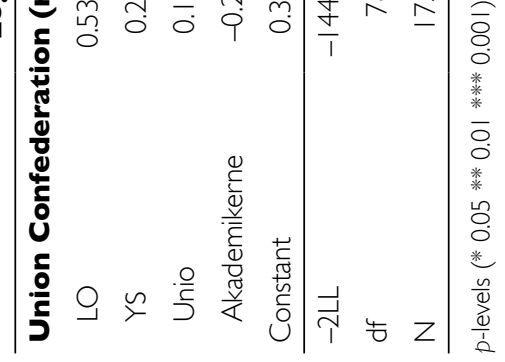


Table 7a Preference for level of wage negotiation. Local level is reference category.

\begin{tabular}{|c|c|c|c|c|c|c|c|c|}
\hline \multirow[b]{3}{*}{ Independent variables } & \multicolumn{4}{|c|}{ Unadjusted } & \multicolumn{4}{|c|}{ Adjusted } \\
\hline & \multicolumn{2}{|c|}{ Central } & \multicolumn{2}{|c|}{ Individual } & \multicolumn{2}{|c|}{ Central } & \multicolumn{2}{|c|}{ Individual } \\
\hline & logit & se & logit & se & logit & se & logit & se \\
\hline \multicolumn{9}{|c|}{ Union Confederation (ref: LO) } \\
\hline YS & $-0.517^{* * * * *}$ & 0.078 & 0.144 & 0.128 & $-0.558 * * * *$ & 0.083 & -0.003 & 0.130 \\
\hline Unio & $1.067 * * * * *$ & 0.098 & $0.365^{*}$ & 0.171 & $0.327 * * *$ & 0.113 & 0.074 & 0.184 \\
\hline Akademikerne & $-1.204 * * * * *$ & 0.082 & $0.313 * *$ & 0.116 & -1.098 ***** & 0.098 & 0.061 & 0.129 \\
\hline Independent & $-1.454 * * * *$ & 0.111 & 0.214 & 0.145 & $-1.119 * * * *$ & 0.118 & 0.227 & 0.150 \\
\hline Do not know & $-0.458^{* * * * *}$ & 0.115 & $0.458 * * *$ & 0.169 & -0.587 ***** & 0.125 & $0.360 *$ & 0.174 \\
\hline Not a member & -1.104 ***** & 0.062 & 1.496 **** & 0.086 & -0.865 **** & 0.068 & 1.364**** & 0.091 \\
\hline
\end{tabular}

\section{Socio-economic status group (ref unskilled, low wage)}

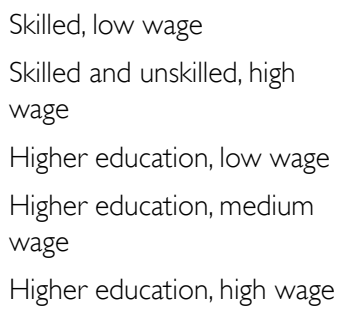

$\begin{array}{cccc}0.024 & 0.085 & 0.112 & 0.109 \\ -0.260 * * & 0.090 & 0.147 & 0.108 \\ 0.043 & 0.087 & -0.200 & 0.113 \\ -0.278 * * * & 0.084 & 0.114 & 0.101 \\ -0.464 * * * & 0.112 & 0.317 * * & 0.120\end{array}$

Control variables

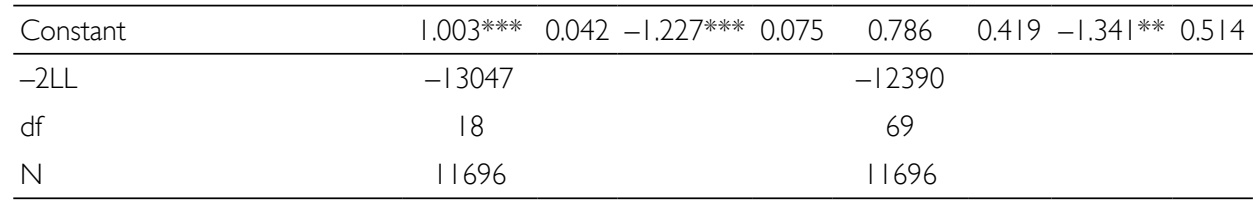

p-levels (* $0.05 * * 0.01 * * * 0.001$ ). Control variables: gender, age, age squared, industrial sector, sector, part-time employment, management position, year and party political preference.

The analysis shows large and significant differences in the preference for central negotiations. The highest support for central negotiations is found among Unio members $(80 \%)$, followed by LO (62\%), YS (50\%) and Akademikerne (35\%). Non-members are least in favour of central negotiations $(25 \%)$.

Approximately $23 \%$ and $31 \%$ of the members of LO and YS, respectively, prefer local negotiations, compared to $43 \%$ of Akademikerne. Only $10 \%$ of the members of Unio prefer local negotiations.

Finally, only a minority of members in all union confederations prefer individual negotiations. The list, in descending order, reads Akademikerne 17\%, YS 11\%, LO $7 \%$ and Unio $4 \%$. The comparative figure among non-members is $35 \%$. Undoubtedly, an adjustment for compositional effects between the unions will attenuate these differences.

However, surprisingly, the differences remain significant and quite large, even after adjusting for socio-economic position, gender, industrial sector, managerial/ supervisor position and political preference/voting behaviour. Most support for 
Figure 2a Preference for level of wage negotiation according to Union Confederation membership.

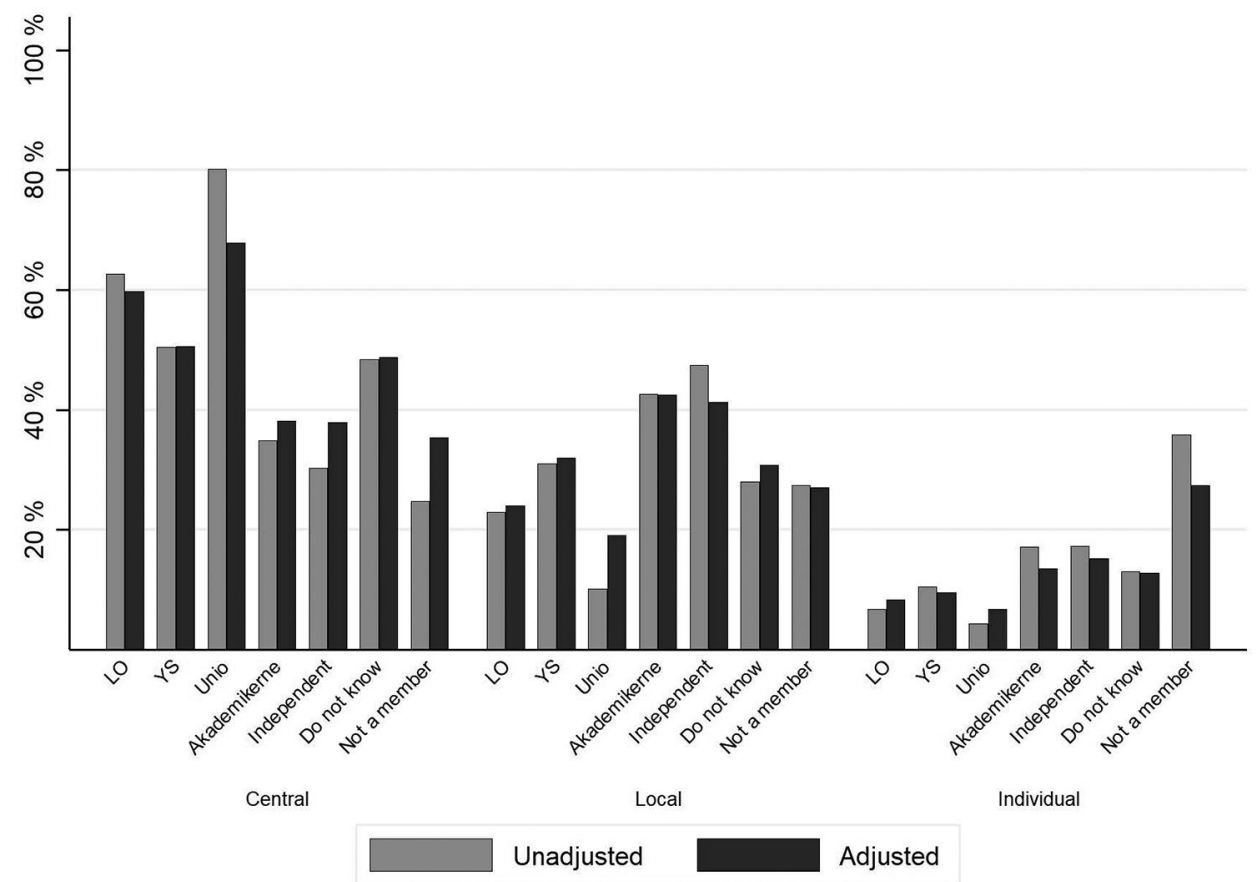

central negotiations is still found among members of Unio (80\%), followed by LO $(62 \%)$, YS (50\%) and Akademikerne (38\%). The only difference is that, holding SES constant, members of Akademikerne display a slightly increased preference for central negotiations.

Next, members of Akademikerne (40\%) and YS (32\%) are more inclined to prefer local negotiations compared to members of LO $(23 \%)$ and Unio $(11 \%)$.

Finally, adjusting for controls have no impact on the preference for individual negotiations, except among members of Akademikerne, among whom we find a slight decrease from $17 \%$ to $13 \%$ in favour of individual negotiations.

Figure $2 \mathrm{~b}$ displays differences in preference according to union confederation membership within SES-groups (Table 7b).

Figure $2 \mathrm{~b}$ clearly shows that union members in the low education SES groups prefer central negotiations independent of to which union confederation they belong. Moreover, the high-wage group falls to the left of those with low wage, which indicates a lower preference for central negotiations among high earners.

Among those with higher education, Unio members display a stronger preference for central negotiations than LO members, except among those with higher education and high wages. As mentioned previously, this may be explained by the relatively high percentage of managers in this group. Akademikerne and non-members show similar low preferences for central negotiations.

The analysis shows that there are small variations in preference for central negotiations across the SES groups. All in all, education does not seem to matter much for 


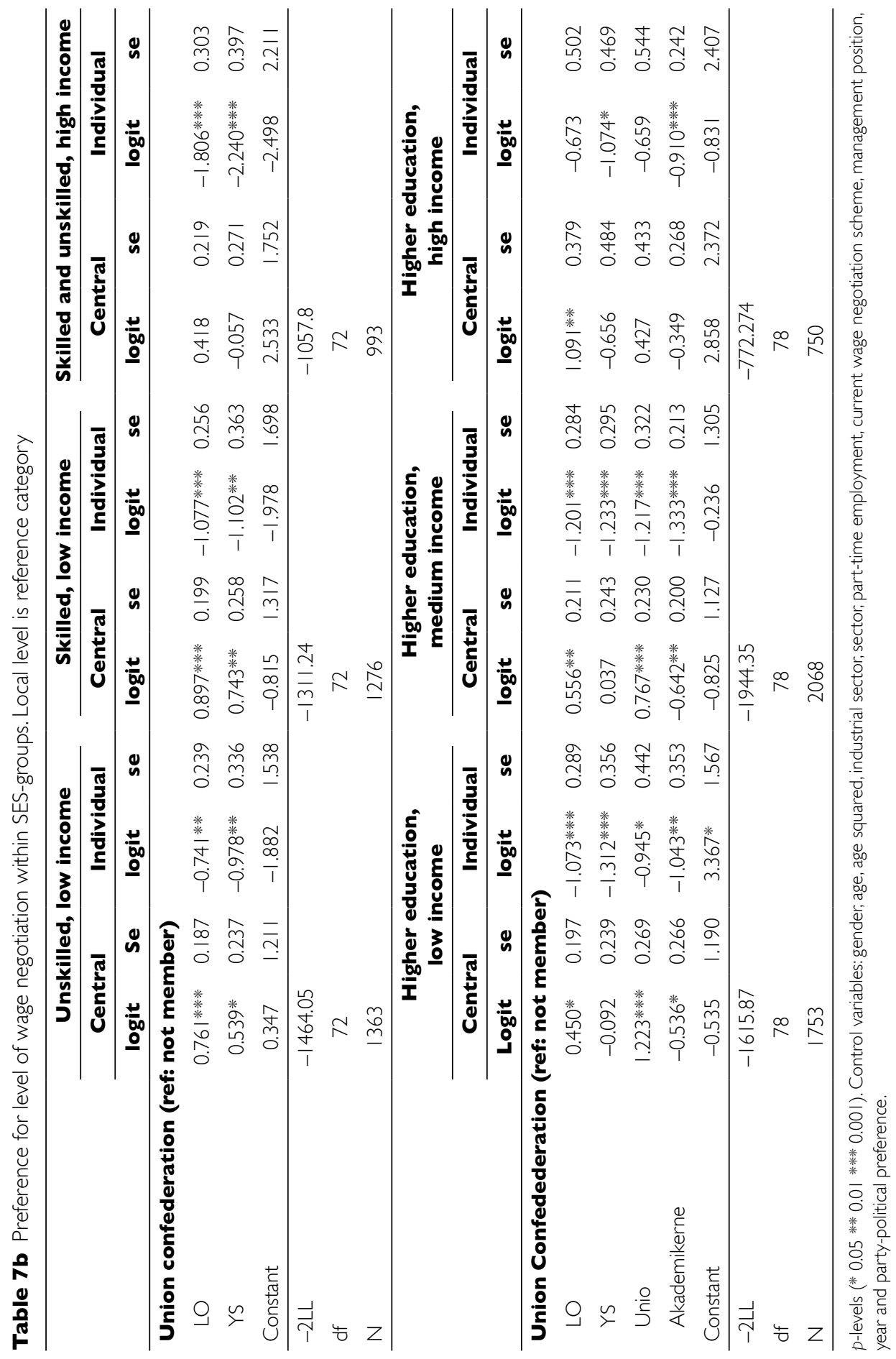


Figure 2b Preference for level of wage negotiation within SES-categories according to Union Confederation membership.

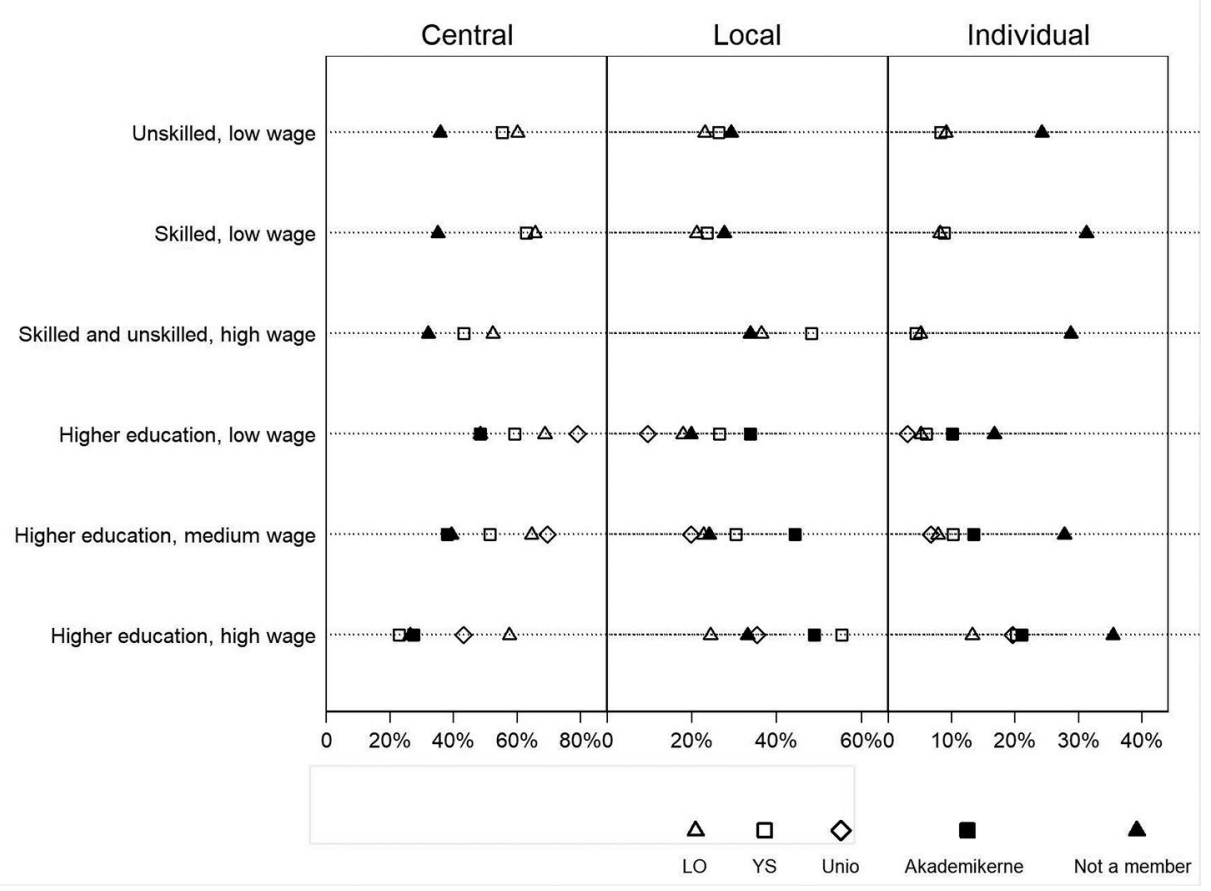

the preferences, but we can observe a gradient for income, as the higher-earner groups among those with low and high education fall to the left of those with low income.

\section{Discussion}

The purpose of this article was to explore how social class position and union strategies shape individuals' bargaining preferences and their attitudes towards wage inequalities. Our objective was to put structural explanations based on social class position into dialogue with more agency-oriented perspectives based on the formative role of union strategies. This led us to explore whether union strategies, at the level of union confederations, can explain differences in attitudes towards wage dispersion and preferred bargaining structures. We found that union confederation membership has a direct association on such attitudes and preferences. The results show that the majority of workers prefer smaller wage dispersion, but also that this attitude is most widespread among members of LO and Unio, regardless of their socio-economic status. Members of Akademikerne tilt more towards larger wage dispersion. Adjusting for party-political preference further strengthens our findings, since this presumably have a large impact on ideological and normative questions, such as social inequalities. Our analysis suggests then, that above and beyond ideological orientations and position in the social class schema, unions are formative of their members' attitudes. 
Unions might be formative in several ways. First, merely by having established a segmented union movement, unions include or exclude workers according to occupation, and workers will choose to belong to unions that reflect their (perceived) interests. This will presumably influence union identities and strategies, amongst others by majority rule. Secondly, making separate wage claims, this will also foster the segmentation of the labour market, thus furthering the material inequalities between the groups. In other words, unions are, by way of their structure and identity-building project, involved in the social construction of occupational groups and their relative social and material privileges. As seen above, some would argue that union profiles are the outcome of selection processes, and that, as a corollary, the characteristics of their members shape union strategies. Our findings, on the other hand, suggest that the union confederations are involved in relative positioning through actively and strategically producing what the workers select. Thirdly, and more importantly, unions are subsequently formative of their members through their communication and substantiation of chosen strategies. We saw above that while Akademikerne draw explicitly on discourses of equity, and state a normative stance in the direction of greater societal acceptance for differentiation, LO, on the other hand, clearly state income equalisation as a main objective, emphasizing also societal redistribution. We argued that Unio draw on both discourses of equity, in statements such as 'education should pay off', and equalisation, through broader notions of societal solidarity, where the former is subsumed by the latter. In our analysis of union strategies, we found YS the least explicit, and we argued that the organisation draws neither on the principle of equity nor equality, rendering income inequality a sheer quantitative measure, and hence the question of fairness impossible to answer.

The last research question investigated whether union confederation membership predicted bargaining preferences. Differences in preferred bargaining structures are striking, even after adjusting for party-political preference and socio-economic status, and substantially larger than the differences observed in attitudes towards wage dispersion. Our hypothesis is that the strategies of union confederations affect at what level members prefer wage setting. One reason why observed differences in preferred bargaining structures are larger than in attitudes towards wage dispersion may be that the latter is more tied up with hegemonic normative stances towards equality in social-democratic Norway, while the level of wage setting appears less political and value-laden.

Preferred bargaining structures has, however, been one of the most disputed topics in the Norwegian union movement recently, and the confederations pursue separate strategies (Fennefoss \& Høgsnes 2008). We saw above that while Akademikerne make explicit reference to wage setting at the local and even individual level, Unio and LO favour centralised collective bargaining of nation-wide agreements. Our analysis shows that the majority of members in LO and Unio are in favour of such centralised bargaining. Whereas the preferences among LO members show small shifts across wage segments, we observe marked change among Unio members in the low-, medium- and high wage sections. Unio members in the low- and medium wage sections are more positive to centralized wage bargaining than LO members, but this is reversed in the high-wage section. There are at least two possible explanations to this finding, and they are not mutually exclusive. First, close to the individual-oriented tradition of workers' preferences and political economic theory, it could be that workers' preferences are informed 
purely by assessments of one's own self-interest in collective organisation and centralised bargaining. In this regard, low and medium-wage earners in Unio would presumably assume that their wage outcomes would be more favourable if they stick together bargaining against other highly educated groups. Similarly, and by extension, explaining the different preferences of Unio members in the low-, medium and high-wage sections might boil down to more relative considerations of fairness and thus reference points, that is with whom workers compare their wages and thus at what level of generality equality is defined and solidarity constructed. It could be argued that the members of Unio, who are largely highly educated and professionals, prefer central negotiations as a result of them being largely public sector workers. Thus, the mechanism suggested by Kitschelt and Rehm (2014) and Svallfors (1997), that occupational experience of interacting with members of all social classes might foster egalitarian values, might explain their deviance.

Secondly, as mentioned in out theoretical framework, professional unions, such as the affiliates of Unio, might seek to achieve and maintain privilege through closure strategies in collective bargaining (Wallerstein \& Golden 1997; Campbell \& Haiven 2011; Arndt 2018). This would entail union strategies focussing on a high degree of intra-group equality and solidarity, arguably potentially to the detriment of inter-group solidarity, and as a result, preferences for increasing inter-group inequalities. However, based on Scheuer's (1986) framework these workers should form professional-oriented unions seeking to increase the status for their constituency to the detriment of strategies aimed at equalisation.

For Akademikerne, it seems that the framework developed by Scheuer (1986) has more explanatory power, especially when we take the dynamics of the 2014 and 2016 central negotiations in the public sector into account. Since Akademikerne and Unio assumed opposite ends regarding local versus central negotiations, it becomes clear that we need to draw on more than one single perspective in our attempts at providing an explanation. As seen above, Akademikerne make explicit reference to wage setting at the local, and even individual, level in their strategies, while at the other end of the continuum, Unio and LO explicitly favour centralised and nation-wide collective agreements. On the part of Unio, this is to the extent that its affiliates established a new union confederation instead of joining Akademikerne on precisely this issue. Our analysis clearly shows that not many workers are in favour of individual wage negotiations, not even in Akademikerne, although a larger share of their members actually does prefer this.

Our study has two caveats. First, the lack of longitudinal data means that we cannot disentangle endogeneity of workers selecting into unions and the influence of union strategy on attitude and preference formation. Although our models include extensive controls of sources of attitude formation, including political party affiliation and industrial sector, there might be other sources of influence correlated with union membership that is not observed in our models. One example is occupational task structure, previously shown to affect attitude formation (Kitschelt and Rehm 2014). ${ }^{3}$ Secondly, although the observed differences between the social classes and unions, the main picture is that most workers are against larger wage dispersal in society and union members do prefer collective to individualised bargaining. Nevertheless, our analysis confirms a strong correlation between union confederation and attitudes 
towards the level of wage dispersion in society, and preference for centralised, local or individualised wage bargaining. In terms of support for the redistributive welfare state, these results highlight the importance of union strategy as a political force in society.

\section{Conclusion}

Our point of departure was to explore two competing perspectives on bargaining preference and attitude formation when it comes to wage inequality. The first perspective suggests that social class position informs attitudes and preferences, whereas the second perspective is on the role of unions as political agents constructing, defining and shaping the attitudes of their members on justice, solidarity and wage setting. Our results corroborate previous research in that SES continues to be highly correlated with such preferences and attitudes. However, and more interestingly, we also find that union confederation membership has a direct association with the same attitudes and preferences, after adjusting for social class, party-political preference and other control variables. This leads us to the conclusion that, above and beyond ideological orientation and SES, unions are formative of the members' attitudes.

We argued that unions are, by way of their structure and identity-building project, involved in the social construction of occupational groups and their relative social and material privilege. We saw that while Akademikerne draw explicitly on discourses of equity and assume a normative stance in the direction of greater societal acceptance for differentiation at one extreme, LO, at the other, clearly state equalisation and redistribution as major objectives. In between these two, Unio draw on both discourses, while YS draw on neither. Our analyses found that union confederation membership significantly predict attitudes and preferences, net of SES and other controls. These findings have important, positive, implications for the union movement. They largely point in the direction of unions not being structurally determined by their external context and a subsequent self-selected membership constituency, but are rather active in the construction and shaping of that context and their own constituency. This means that they have considerable leeway, which also increases the importance of reflecting upon the strategies chosen.

In addition to the important empirical findings, this article shows the merits of synthesizing competing perspectives and different data. This synthesising has broadened our understanding of preferred bargaining structures and attitudes to wage inequalities and allowed us to study the social construction of notions of fairness, equality and equity, of which unions are part. We would thus argue that such synthesizing is necessary in order to gain a better understanding of attitudes and preferences, by including how union strategies shape these through contemporary and future strategies in the analyses. Furthermore, and maybe most importantly, these results highlight the importance of union strategy as a political force in society, especially in building support for the redistributive welfare state. We would argue that these theoretical insights would hold for union movements in other contexts, particularly in the Nordic countries which share the long history of social-democratic hegemony and feature strong and highly visible union movements capable of making a material impacts and forming public opinion. On the 
other hand, we would argue that our analytical model and empirical findings would not be as easily generalized, not even in a Nordic context. Despite unions playing a more prominent role in Nordic politics and economics than they do in most other countries, the structure and segmentation of the union movement varies considerably. Compared to the four union confederations in Norway, which to some extent have overlapping constituencies and thus compete for some of the same (potential) members, Denmark has only two main confederations, Sweden and Finland have three. In Sweden and Finland there has, however, been attempts at cooperating and even merging, signaling that the confederations do not fundamentally differ on policies.

\section{Acknowledgements}

This study was funded by Norwegian Research Council, grant. no: 237039.

\section{References}

Alesina, A. F., \& Giuliano, P. (2009). Preferences for redistribution (No. w14825).

Alt, J., \& Iversen, T. (2017). Inequality, labor market segmentation, and preferences for Redistribution, American Journal of Political Science 61(1): 21-36. doi: https://doi. org/10.1111/ajps.12264.

Arndt, C. (2018). White-collar unions and attitudes towards income inequality, redistribution, and state-market relations, European Sociological Review 34(6): 675-693. doi: https://doi.org/10.1093/esr/icy033.

Barth, E., Moene, K., \&Wallerstein, M. (2003). Likhet under press. Utfordringar for den skandinaviske fordelingsmodellen, Oslo: Gyldendal.

Becher, M., \& Pontusson, J. (2011). Whose interests do unions represent? Unionization by income in Western Europe. In Comparing European workers Part B: Policies and institutions. Emerald Group Publishing Limited. doi: https://doi.org/10.1108/S02772833(2011)000022B00.

Bergene, A. C. \& Mamelund, S. E. (2015). Fit for fight? A cross-sectional study of union apathy in Norway, Economic and Industrial Democracy 38(2): 1-21. doi: https://doi. org/10.1177/0143831X14566889.

Campbell, S. \& Haiven, L. (2011). Struggles on the frontier of professional control: Leading cases from Canada, Economic and Industrial Democracy 33(4): 669-689. doi: https:// doi.org/10.1177/0143831X11426805.

Castree, N., Coe, N. M., Ward, K. \&Samers, M. (2004). Spaces of work, London: Sage.

Checchi, D., Visser, J., \&Van de Werfhorst, H. G. (2010). 'Inequality and union membership: The influence of relative earnings and inequality attitudes', British Journal of Industrial Relations 48(1): 84-108. doi: https://doi.org/10.1111/j.1467-8543.2009.00757.x.

Elster, J. (1989). 'Social norms and economic theory', The Journal of Economic Perspectives 99-117. doi: https://doi.org/10.1257/jep.3.4.99.

Fennefoss, A. (1996). 'Organisasjoner, klassifikasjoner og klasser’, Sosiologisk Årbok, Vol 2. $127-152$.

Fennefoss, A., \&Høgsnes, G. (2002). 'Lønnsoppgjøret 2002: Bakgrunn, forløp og konsekvenser', Søkelys på arbeidslivet 19(2): 181-191.

- (2004). 'Lønnsoppgjøret i 2004 - en oppsummering og noen refleksjoner', Søkelys på arbeidslivet 21(2): 225-231. 
(2006). 'Lønnsoppgjøret i 2006 - noen hovedtrekk', Søkelys på arbeidslivet 23(2): 213-220.

- (2008). 'Lønnsoppgjøret 2008: Oppsummering og analyse', Søkelys på arbeidslivet 25(3): 381-399.

Fennefoss, A., Høgsnes, G., \&Larsen, K. A. (2000). 'Lønnsoppgjøret 2000 - og fremtidens lønnsdannelse', Søkelys på arbeidslivet 17(2): 189-202.

Hyman, R. (2001). Understanding European Trade Unionism: Between Market, Class and Society, SAGE: London.

Høgsnes, G. (1989). 'Wage bargaining and norms of fairness-a theoretical framework for analysing the Norwegian wage formation', Acta Sociologica 32(4): 339-357. doi: https:// doi.org/10.1177/000169938903200402.

Høgsnes, G. (1999). Krone for krone. Lønnsforhandlinger og -fordelinger, Oslo: Ad Notam.

Iversen, T. \& Soskice, D. (2001). An asset theory of social policy preferences, American Political Science Review: 875-893. https://www.jstor.org/stable/3117719.

Jones, G. S. (1983). Languages of class. Studies in English working class history 1832-1982, Cambridge Universiy Press: Cambridge.

Kim, S. E., \& Margalit, Y. (2017). Informed preferences? The impact of unions on workers' policy views, American Journal of Political Science 61(3): 728-743. doi: https://doi. org/10.1177/0010414013516066.

Kitschelt, H., \&Rehm, P. (2014). 'Occupations as a site of political preference formation', Comparative Political Studies 47(12): 1670-1706.

Kjellberg, A. (2000). Sweden. Trade Unions in Western Europe since 1945 (The Societies of Europe), 605-655.

Messel, J. (2010). LO og "de nye gruppene”: konseptualiseringen av arbeidstakerne 19751989. PhD dissertation, Facutly of Humanities, University of Oslo.

Mosimann, N. \& Pontusson, J. (2017). Solidaristic unionism and support for redistribution in contemporary Europe. World Pol., 69, 448. doi: https://doi.org/10.1017/ S0043887117000107.

Osberg, L. \& Smeeding, T. (2006). “Fair” inequality? Attitudes toward pay differentials: the United States in comparative perspective', American Sociological Review 71(3): 450473. doi: https://doi.org/10.1177/000312240607100305.

Pernicka, S. \& Lücking, S. (2012). 'How knowledge shapes collective action: professionalism, market closure and bureaucracy in the fields of university and non-university research', Journal of Industrial Relations 54(5): 579-595. doi: https://doi. org/10.1177/0022185612454958.

Pontusson, J. (2013). Unionization, inequality and redistribution, British Journal of Industrial Relations 51(4): 797-825. doi: https://doi.org/10.1111/bjir.12045.

Ritzman, R. L. \& Tomaskovic-Devey, D. (1992). 'Life chances and support for equality and equity as normative and counternormative distribution rules', Social Forces 70(3): 745763. doi: https://doi.org/10.1093/sf/70.3.745.

Scheuer, S. (1986). Fagforeninger mellem kollektiv og profession, København: Nyt fra Samfundsvidenskaberne.

Scheuer, S. (1993). 'Leaders and Laggards: Who Goes First in Bargaining Rounds?' in T. P. Boje and S. E. Olsson Hort (eds.) Scandinavia in a New Europe. pp. 239-268. Oslo: Universitetsforlaget.

Silver, B. (2003). Forces of Labor: Workers' Movements and Globalization Since 1870, Cambridge Studies in Comparative Politics: Cambridge.

Svallfors, S. (1993). 'Dimensions of inequality: A comparison of attitudes in Sweden and Britain', European Sociological Review 9(3): 267-287. doi: https://doi.org/10.1093/oxfordjournals.esr.a036681. 
Svallfors, S. (1997). 'Worlds of welfare and attitudes to redistribution: A comparison of eight western nations', European Sociological Review 13(3): 283-304. doi: https://doi. org/10.1093/oxfordjournals.esr.a018219.

Wallerstein, M., and Golden, M. (1997). 'The Fragmentation of the Bargaining Society Wage Setting in the Nordic Countries, 1950 to 1992', Comparative Political Studies 30(6): 699-731. doi: https://doi.org/10.1177/001979399705000301.

\section{Notes}

${ }^{1}$ These are individuals who are members of a trade union, but they do not know to which confederation their union belong, or they do not know if they belong to one at all. It is only $4 \%$ of the sample that answer 'do not know', but among these, $44 \%$ have higher education. One explanation might be that the professional associations' confederations, Unio and Akademikerne, are younger federations compared with LO, and organize established professional associations such as the Norwegian medical association, the lawyer's association, etc.

${ }^{2}$ As a robustness check, we also performed the analyses with 80 industry*education fixed-effects $(>50$ observations) to investigate whether we observe the same associations between attitudes and confederations among persons in similar occupational positions. The results are highly similar (see Appendix B).

${ }^{3}$ The analyses in Appendix B, however, with industry*education controls did show similar results to the SES-models. 


\section{Appendix A}

Results with wage deciles and education levels.

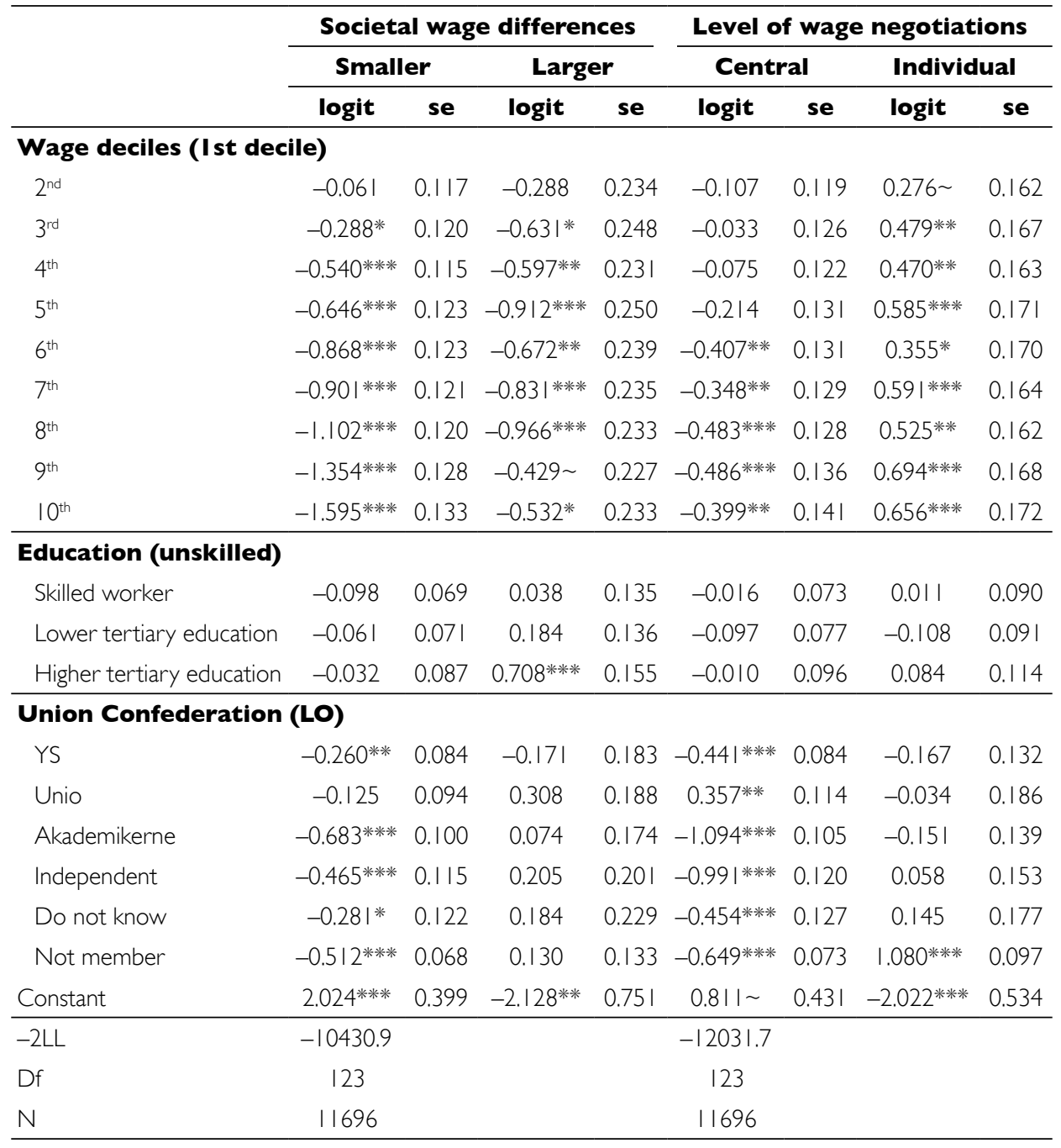

p-levels $(\sim 0.10, * 0.05 * * 0.01 * * * 0.001)$. 
Figure Ala Preference for wage differences according to Union Confederation membership. Controls for wage decile and education level.

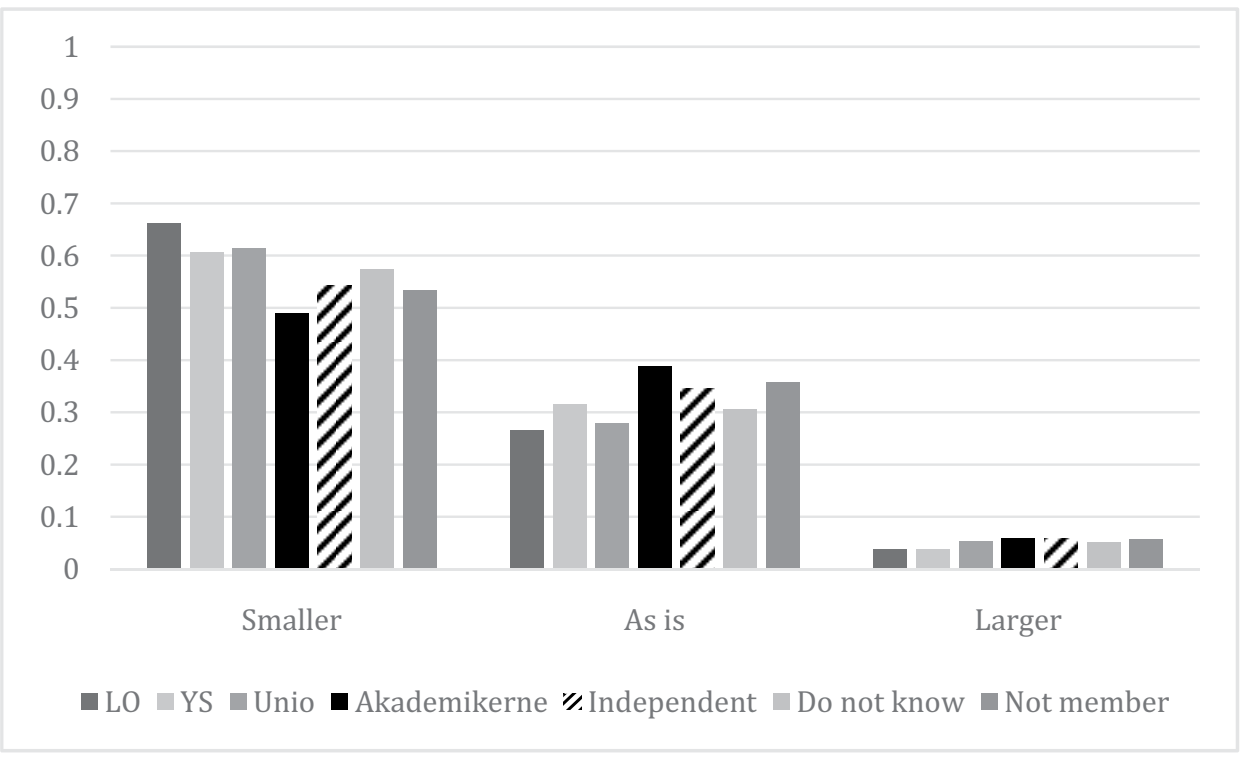

Figure A I b Preference for wage differences according to Education level. Controls for Union Confederation membership and wage decile.

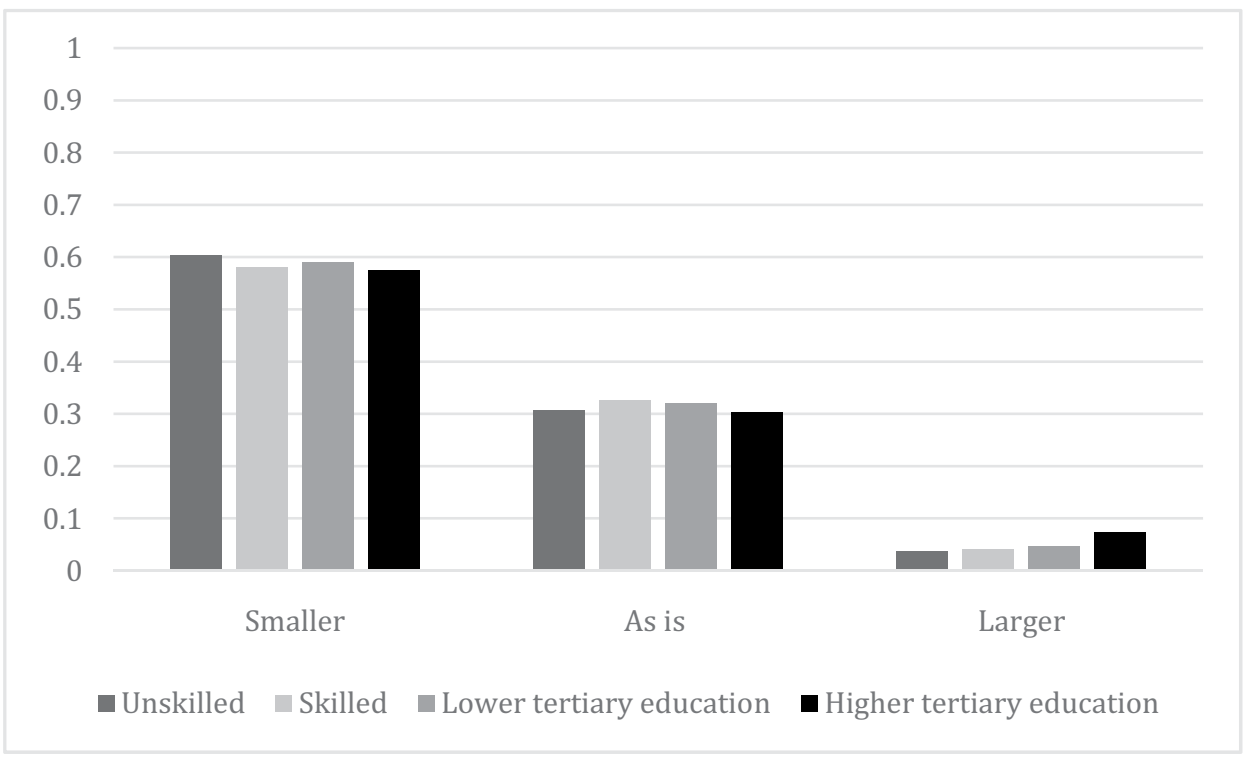


Figure A Ic Preference for wage differences according to Wage decile. Controls for Union Confederation membership and education level.

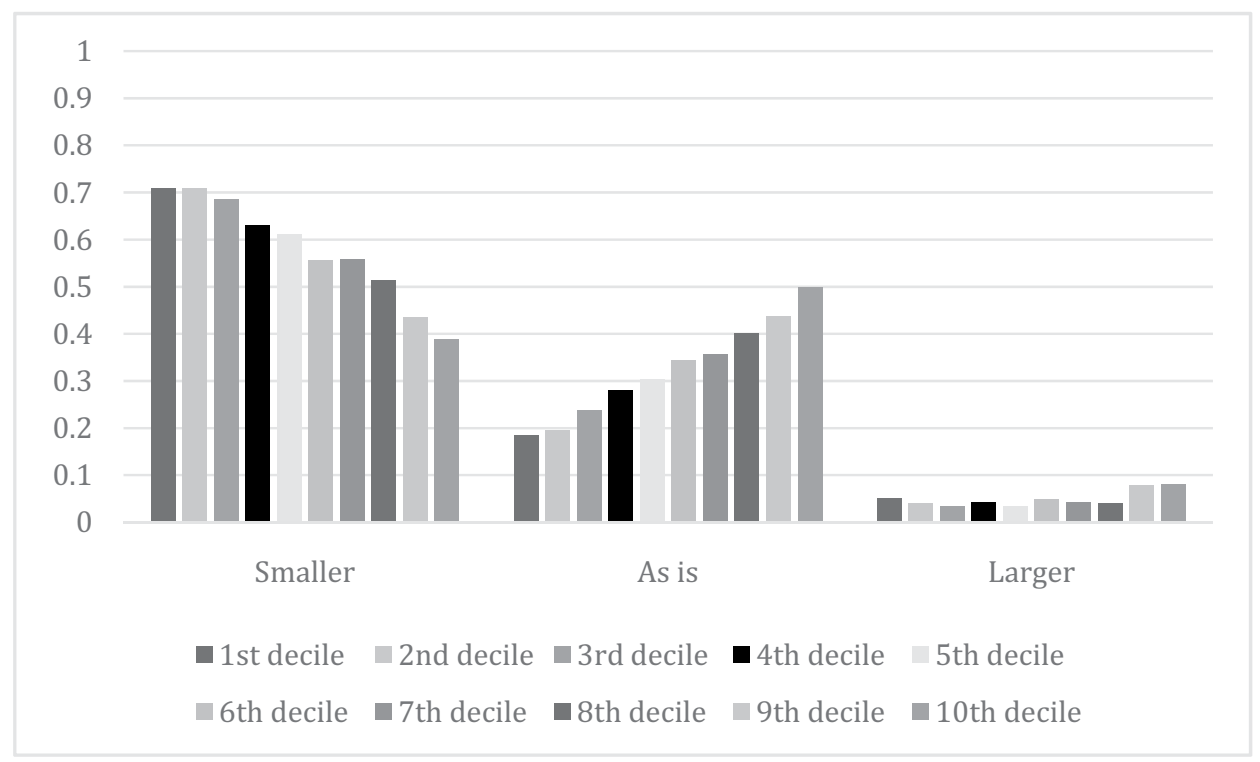

Figure A2a Preference for level of wage negotiation according to Union Confederation membership. Controls for wage decile and education level.

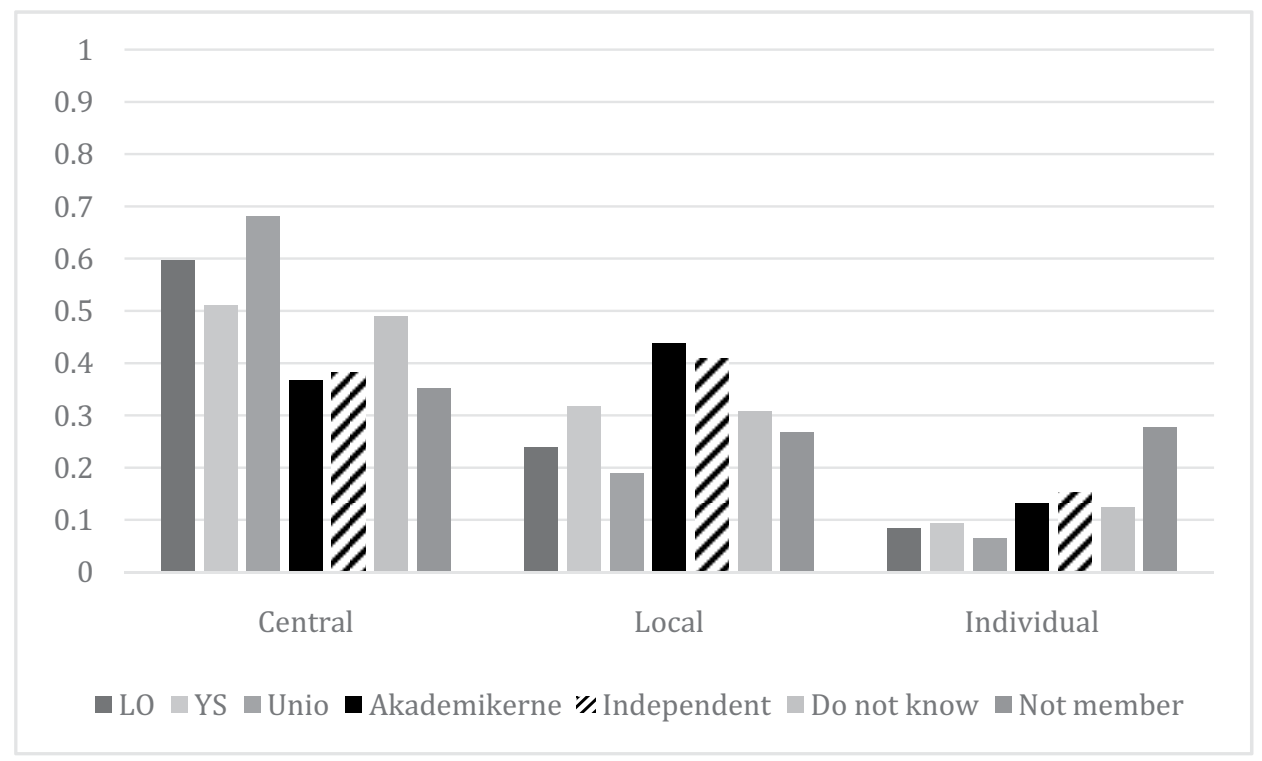


Figure A2b Preference for level of wage negotiation according to Education level. Controls for wage decile and Union Confederation membership.

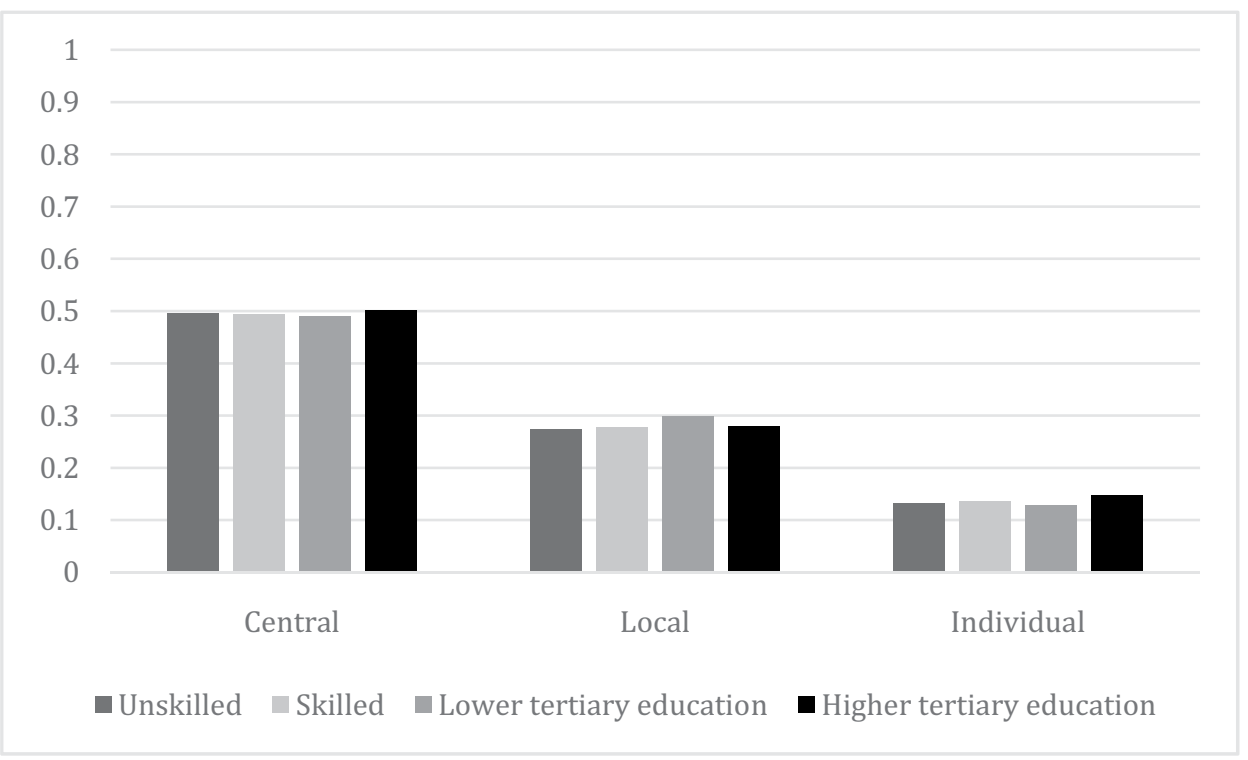

Figure A2c Preference for level of wage negotiation according to Wage decile. Controls for education level and Union Confederation membership.

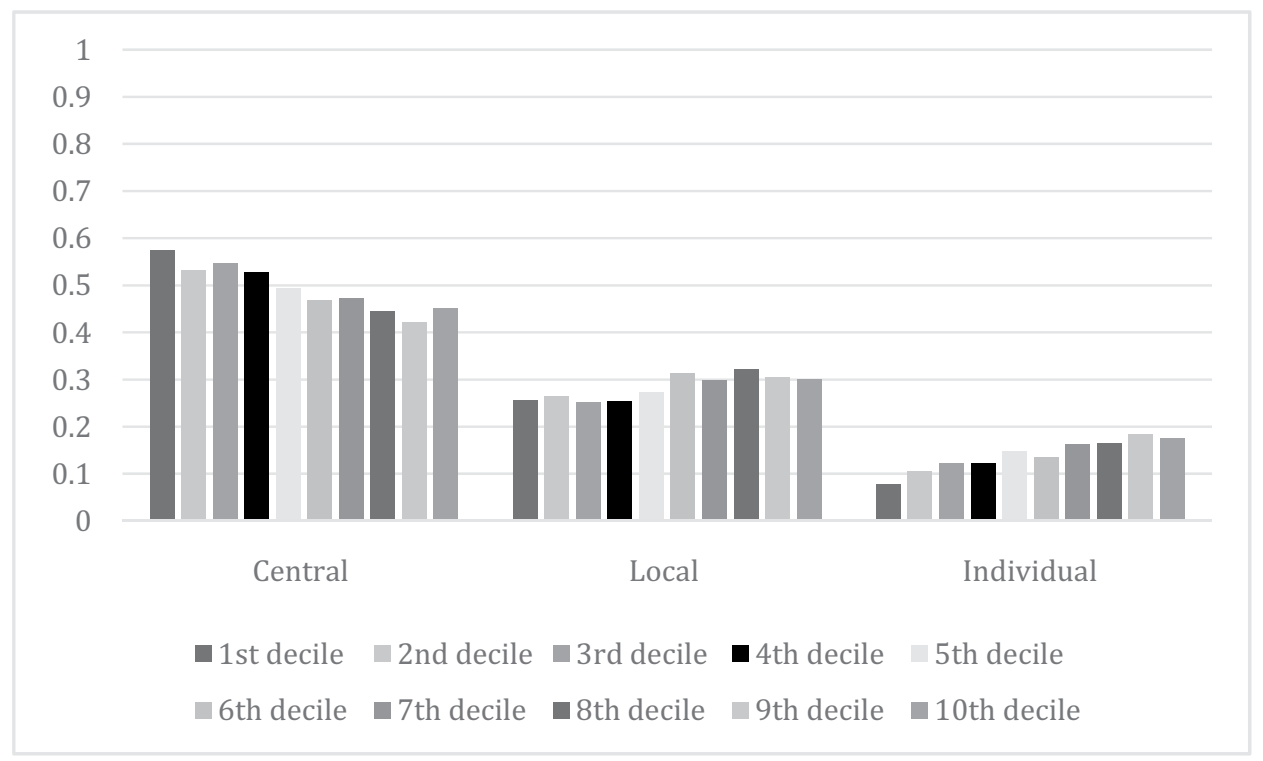




\section{Appendix B}

Table B I Industries

\begin{tabular}{lc}
\hline Public administration & 1,354 \\
\hline Kindergarten, schools & 1,663 \\
\hline Health services & 1,079 \\
\hline Social services & 200 \\
\hline Care services & 417 \\
\hline Defence, policing, judicial system & 341 \\
\hline Industry & 880 \\
\hline Building & 698 \\
\hline Retail & 902 \\
\hline Transportation & 576 \\
\hline Culture, Sports & 267 \\
\hline Media, advertising, PR & 238 \\
\hline Research, analytics & 234 \\
\hline Hospitality & 110 \\
\hline Restaurants & 71 \\
\hline Telecommunication & 599 \\
\hline Banking, insurance & 406 \\
\hline Business support & 406 \\
\hline Oil, gas, enegry & 802 \\
\hline Other & 453 \\
\hline Total & $\mathbf{I I , 6 9 6}$ \\
\hline & \\
\hline
\end{tabular}

Table B2 Education levels

\begin{tabular}{ll}
\hline High school (general education) & 2,541 \\
\hline Vocational certificate & 2,798 \\
\hline Bachelor & 3,636 \\
\hline Master & 2,721 \\
\hline
\end{tabular}

We combine industry*education to create occupational positions. In total 80 combinations of industry*education have an $\mathrm{N}$ above 50 observations. 
Table B3 Multinomial logistic regression with industry*education fixed effects. Comparative to the adjusted effects in table 6a and 7a.

\begin{tabular}{|c|c|c|c|c|c|c|c|c|}
\hline & \multicolumn{4}{|c|}{ Societal wage difference } & \multicolumn{4}{|c|}{ Level of wage negotiation } \\
\hline & \multicolumn{2}{|c|}{$\begin{array}{c}\text { Smaller } \\
\text { differences }\end{array}$} & \multicolumn{2}{|c|}{$\begin{array}{c}\text { Larger } \\
\text { differences }\end{array}$} & \multicolumn{2}{|c|}{ Central } & \multicolumn{2}{|c|}{ Individual } \\
\hline & b & se & b & se & $\mathbf{b}$ & se & $\mathbf{b}$ & se \\
\hline YS & $-0.223 *$ & 0.087 & -0.128 & 0.188 & $-0.440 * * * *$ & 0.089 & -0.220 & 0.138 \\
\hline Unio & -0.150 & 0.100 & 0.261 & 0.195 & $0.279 *$ & 0.119 & 0.091 & 0.193 \\
\hline Akademikerne & $-0.730 * * * *$ & 0.105 & 0.071 & 0.181 & $-1.059 * * * * *$ & 0.110 & -0.089 & 0.145 \\
\hline Independent & -0.454 ***** & 0.118 & 0.241 & 0.206 & $-0.993 * * * *$ & 0.124 & 0.027 & 0.157 \\
\hline Do not know & $-0.249 *$ & 0.125 & 0.194 & 0.233 & -0.449 ***** & 0.130 & 0.181 & 0.180 \\
\hline Not a member & -0.520 ***** & 0.069 & 0.137 & 0.136 & $-0.644 * * * *$ & 0.075 & 1.118 ***** & 0.099 \\
\hline Control variables & \multicolumn{2}{|l|}{ yes } & \multicolumn{2}{|c|}{ yes } & \multicolumn{2}{|l|}{ yes } & \multicolumn{2}{|c|}{ yes } \\
\hline Constant & 2. $104 * * * *$ & 0.437 & $-2.277 *$ & 0.890 & $0.885 \sim$ & 0.471 & $-1.39 \mid *$ & 0.590 \\
\hline$-2 \mathrm{LL}$ & -10284.369 & & & & -|| $8|9.96|$ & & & \\
\hline df & 318.000 & & & & 318.000 & & & \\
\hline$N$ & 11656 & & & & 11656 & & & \\
\hline
\end{tabular}

The control variables are age and age squared, gender, industrial sector, public/private sector, part-time employment, wage decile, supervisory/management position, current wage-setting arrangement and party-political preference. 